\title{
Multi-factorial modulation of colorectal carcinoma cells motility - partial coordination by the tetraspanin Co-029/tspan8
}

\author{
Yingying Zhu ${ }^{1,2,3, *}$, Naouel Ailane ${ }^{1,2, *}$, Monica Sala-Valdés ${ }^{1,2}$, Farhad Haghighi-Rad ${ }^{1,2}$, \\ Martine Billard ${ }^{1,2}$, Viet Nguyen ${ }^{2,4}$, Raphael Saffroy ${ }^{2,5,6}$, Antoinette Lemoine ${ }^{2,5,6}$, Eric \\ Rubinstein ${ }^{1,2}$, Claude Boucheix ${ }^{1,2}$, Céline Greco ${ }^{1,2,7}$ \\ ${ }^{1}$ Inserm, UMR-S 935, SFR André Lwoff, Villejuif, France \\ ${ }^{2}$ Université Paris-Sud 11, Paris, France \\ ${ }^{3}$ Department of Oncology, Tongji Hospital, Huazhong University of Science and Technology, Wuhan, Hubei Province, China \\ ${ }^{4}$ Inserm, UMS-33, SFR André Lwoff, Villejuif, France \\ ${ }^{5}$ Inserm UMR-S 1193, SFR André Lwoff, Villejuif, France \\ ${ }^{6}$ AP HP, Hôpital Paul-Brousse, Department of Biochemistry, Villejuif, France \\ ${ }^{7}$ AP HP, Hôpital Necker, Department of Pain and Palliative Medicine, Paris, France \\ *These authors have contributed equally to this work \\ Correspondence to: Céline Greco, email: celine.greco@inserm.fr \\ Keywords: Co-029/tspan8, colorectal carcinoma, cell motility, mycoplasmas, EGFR \\ Received: May 20, $2016 \quad$ Accepted: February 20, $2017 \quad$ Published: March 16, 2017 \\ Copyright: Zhu et al. This is an open-access article distributed under the terms of the Creative Commons Attribution License \\ (CC-BY), which permits unrestricted use, distribution, and reproduction in any medium, provided the original author and source \\ are credited
}

\section{ABSTRACT}

Colorectal carcinoma cells Isreco1 display an ability to migrate controlled by a complex set of signals issued from the membrane. By comparing cells infected by mycoplasmas and mycoplasmas free cells, we have established that basal 2D migration is dependent on a double signal mediated by the collagen receptors integrins alpha1/2 and the Toll-Like receptor TLR2. The signal issued from mycoplasmas can be replaced by a TLR2 ligand and the functional effect is neutralized by silencing of MyD88. Following previous observation that downregulation of E-cadherin/p120 catenin increases cell motility, we now report that EGFR or CD44 inhibition have a similar effect on cell motility that is restricted to tetraspanin Co-029/tspan 8 transduced IsrecoI cells (Is1-Co029). The modulation of cell migration linked to EGFR or CD44 can be neutralized by antagonizing Co-029 with the mAb Ts29.1 or by RNA interference. Altogether these data point to a crucial role of Co-029 in the modulation of colon cancer cell motility which could be related to the protumoral effect reported for this tetraspanin. Among surface molecules able to mediate Co-029 function, E-cadherin, EGFR and CD44 appear as likely candidates.

\section{INTRODUCTION}

Cell motility has attracted considerable interest because of its involvement in normal tissue development and repair but also in tumor invasion and metastasis [1]. Frequently linked with proliferation and survival, this biological program has been defined as "invasive growth" $[2,3]$. Depending on the cells and their environment, extracellular signals may trigger various aspects of this program. The obvious consequence of these biological activities is that they can be targeted for the treatment of tumors and are therefore widely investigated.

We have shown in a previous work that motility of the Isrecol colon carcinoma cells is triggered by a collagen I substrate [4]. Whereas Isreco1 cells don't move on tissue culture plastic (TCP), they become intensely motile in an integrin dependent mechanism when a collagen I substrate is added. These cells display a regular pattern of migration as shown by single cell tracking that demonstrates a low dispersion of cell speed between individual cells. The expression of the tetraspanin 
Co-029/tspan8, that is considered to have a protumoral, prometastatic effect [5] does not change cell motility but induces an integrin switch and renders cells sensitive to the level of expression of the E-cadherin/p120ctn complex [4]. Indeed, Isreco1 basal cell migration relies on integrin $\alpha 1 \beta 1$ signaling for migration whereas Is $1-\mathrm{Co} 029$ cells are $\alpha 2 \beta 1$ dependent. Silencing of E-cadherin or p120ctn accelerates Is1-Co029 cells whereas no effect is found in Isreco1 cells. A physical association between Co-029 and E-cadherin has been demonstrated by crosslinking and the difference of response of the two cell lines has been shown to be RhoA dependent.

To find a possible molecular connection that would be a hint towards understanding the coordinating role played by Co-029 in cell motility, we used mass spectrometry (MS) for identification of the membrane proteins associated to the closely related tetraspanins Co-029 and CD9. The rationale for this approach is that tetraspanins build multimolecular complexes at cell surface [6-12] with a hierarchical organization in which each tetraspanin (mono- or homo/heteromultimeric) has one or more specific partner(s) to which it associates through protein-protein interactions (captured by chemical covalent cross-linking) and these primary complexes may associate together through tetraspanin-tetraspanin interactions involving membrane cholesterol and palmitoylation. These secondary interactions are revealed by immunoprecipitation of Brij97 lysates.

According to MS data, we have compared, in relation to the expression of $\mathrm{Co}-029$, the contribution of EGFR, a major RTK signaling molecule, and CD44 that are both involved in tumor cell motility $[1,2]$, to determine how their modulation may influence this cellular function. Moreover, an unexpected observation made in the course of this work, i.e. the different pattern of migration of mycoplasma free versus mycoplasma contaminated cells, led us to analyze the role of TLR2 signaling.

\section{RESULTS}

\section{Mycoplasms trigger migration of Isreco1 cells on collagen I}

Among multiple colon carcinoma cell lines tested for single cell migration ability on collagen I, only Isrecol cells transduced or not with the tetraspanin Co029 have a homogeneous pattern of cell migration with a low dispersion of cell speed between individual cells (Supplementary Movie 1 left). Isrecol cells cultured on tissue culture plastic display a rounded morphology, don't move and build clusters of cells upon division whereas the same cells cultured on collagen I move rapidly with an elongated arc or fan shape [4]. Cell lines are regularly checked for the presence of mycoplasma and treated for one month with BM cyclin to remove mycoplasma infection. Upon treatment we observed usually that they nearly completely lost their ability of migration on collagen I (Figure 1A and Supplementary Movie 1). Moreover, mycoplasma free cells had a rounded and spread morphology when cultured on collagen very different from the fan shape morphology of mycoplasma contaminated cells (Figure 1B). The mycoplasma status of the Isreco cell lines was checked before and after treatment. Interestingly, if mycoplasma free cells were cultured with supernatant of infected cells, they recovered their migrating properties after 24 hours incubation and started to migrate at the same speed as untreated cells (Figure 1A). These observations indicate that migration of Isrecol cells is triggered by two mechanisms, the first requiring an integrin-mediated signal triggered by collagen and a second signal that is mycoplasmas dependent. The expression of Co-029 does not modify the speed of the cells [4].

Since epithelial cells interact with microorganisms through pattern-recognition receptors as Toll-like receptors, we decided to explore this pathway. Among TLRs, TLR2 forming homodimers or heterodimers with TLR6 are the target of surface molecules of microorganisms such as lipopeptides and share the MyD88-mediated signaling pathway [13]. The presence of TLR2 in Isreco cells was demonstrated by immunofluorescence (Figure 1C), transcriptomal analysis and quantitative RT-PCR (data not shown). Moreover, we show that PGN, a TLR2 ligand, restores the motility of Isrecol cells on collagen (Figure 1D and Supplementary Movie 2). Treatment of mycoplasma contaminated cells by TLR2 small interfering RNA (siRNA) led to $50 \%$ inhibition of cell migration on collagen (Figure 1D). To identify the mycoplasmas strains, we analyzed several immunoprecipitations performed in the following sections by mass spectrometry for contamination with mycoplasma proteins. We made a compilation of the 91 mycoplasma databases from Uniprot (Release-2016_05). Only proteins from mycoplasma hyorhinis could be detected with more than one specific peptide. The list of proteins is shown in Supplementary Table 1.

In order to identify downstream mediators of TLR2 signaling we investigated the NFkB pathway. We used as positive controls, the addition of TNF $\alpha$ or okadaic acid. Neither of these molecules induced a translocation of NFkB to the nucleus as judged by immunofluorescence using an anti p65NFkB antibody (not shown) or by immunoblot on subcellular protein fractions (Supplementary Figure 1). This suggests that the canonical NFkB pathway is defective in these cells. In agreement with this observation, we didn't observe cytoplasm to nuclear translocation in mycoplasma contaminated Isrecol cells cultured either on plastic or collagen substrates or following stimulation by the TLR ligand PGN (Supplementary Figure 2). In contrast, silencing of MyD88 led to complete inhibition of cell migration (Figure 1E-1F and Supplementary Figure 3). Since MyD88 is required for cell migration in this model, we investigated a possible link between MyD88 and the small GTPase Rac1 which is essential for cell migration. Silencing of Rac1 led also to inhibition of cell migration 
(Figure 1E-1F and Supplementary Figure 3). In addition, Vav proteins have been reported to be critical mediators of LPS induced MyD88-dependent activation of Rac2, leading to the production of reactive oxygen intermediates [14]. The transcriptomal analysis of Isreco cells showed that only Vav2 is expressed (data not shown) and silencing of Vav2 in Isreco1 cells expressing or not Co-029 resulted in a complete block of cell migration in both cell types suggesting this protein as a link between MyD88 and Rac1 (Figure 1E-1F and Supplementary Figure 3).

As epithelial-mesenchymal transition (EMT) can promote tumor motility, we further investigated if the change of morphology and migration potential observed in cells cultured on collagen and either infected by
A

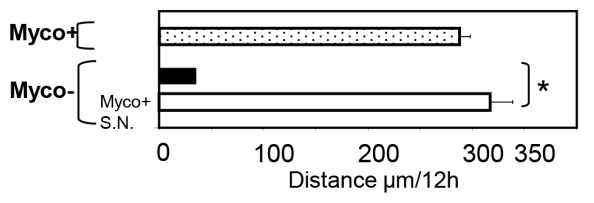

B

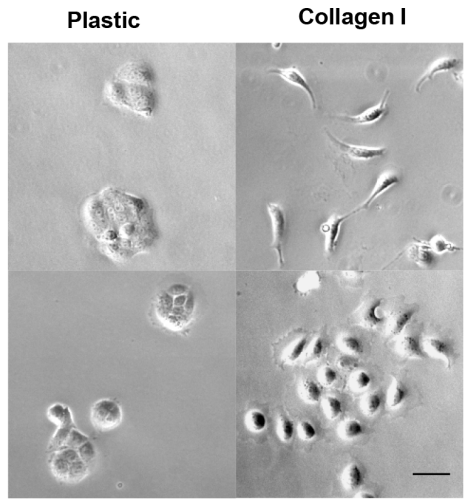

D

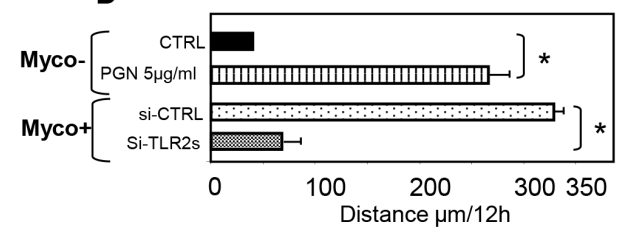

C

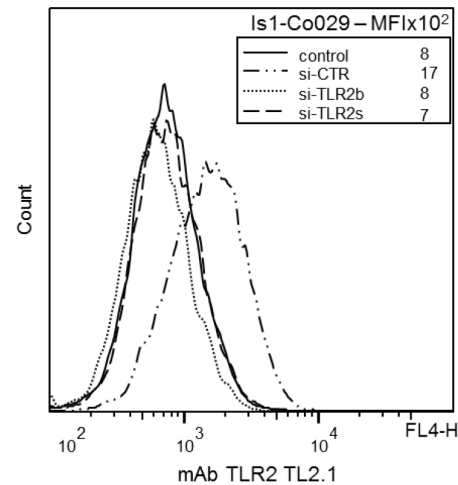

$\mathbf{E}$
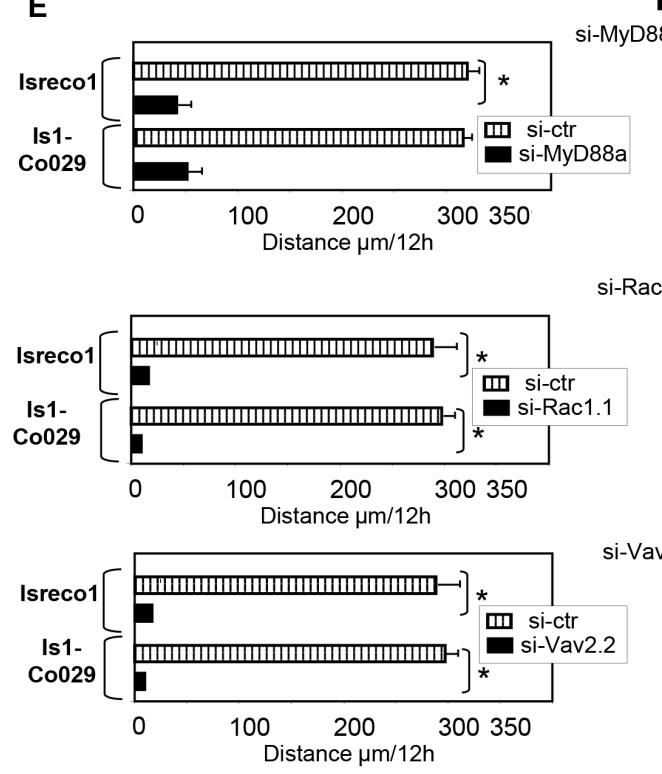

$\mathbf{F}$

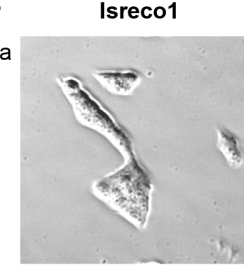

s-Rac1
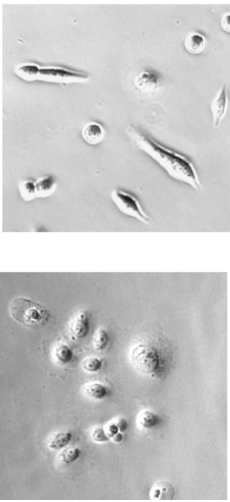

Is1-Co029
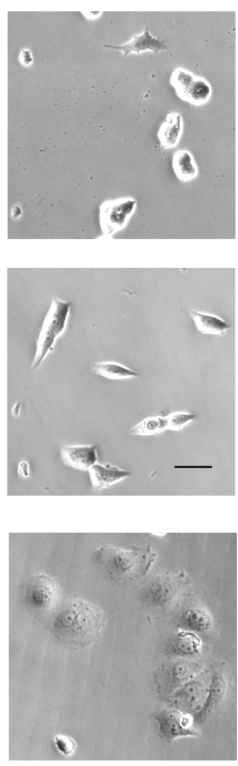

Figure 1: Mycoplasma infection triggers cell motility of Isreco1 cells on collagen I, involvement of TLR2 signalling. (A) Opposite to Myco+ cells, mycoplasma free cells (Myco-) migrate slowly on collagen I substrate (black bar). Addition of mycoplasma infected supernatant (Myco+ S.N.) restores the migration of Myco- cells after 24 hours incubation (white bar). Averaged distance travelled by cells; error bars indicate s.e.m; asterisks indicates $\mathrm{p} \leq .0001$. (B) Cellular morphology according to mycoplasma status and culture substrate. (C) TLR2 expression and RNA interference. (D) The motility of Myco- (black bar) cells is restored by addition of the TLR2 ligand PGN (white bar) whereas RNA interference of TLR2 (si-TLR2s) inhibits migration of Myco+ cells (grey bar). (E) Silencing of Myd88, Vav2 and Rac1 strongly inhibit migration of Isreco1 and Is1-Co029 cells. (F) Silencing of MyD88, Vav2 and Rac1 induces different morphological aspects of Isreco cells that are all associated with profound inhibition of motility. For si-CTRL, a si-RNA directed to tetraspanin CD53 was used. Asterisks indicates $\mathrm{p} \leq .0001$. 
mycoplasmas or stimulated by PGN was associated with molecular markers of EMT. For that purpose we first compared the expression of CK8/18 and vimentin by immunofluorescence in mycoplasma infected and mycoplasma negative cells. Despite the morphological changes when mycoplasma infected cells are plated on collagen, no disappearance of CK8/18 fibers was observed and the vimentin labeling was diffuse and punctuate but not filamentous whatever the cells, mycoplasma status or substrate plating (Supplementary Figure 4A). We also analyzed by quantitative RT-PCR four transcription factors associated with EMT. Twist and Zeb2 mRNA were not detectable in Isreco1(+/- Co-029) cells, whereas there was a generally moderate increase of Snail and Slug when cells were plated on collagen but independently of mycoplasma infection (Supplementary Figure 4B). This indicates that the mesenchymal aspect and behaviour resulting from the costimulation by TLR2 ligands and collagen I is not associated with a strong EMT at molecular level.

The SW480 cell line was chosen for in vivo experiments since they grow more rapidly and homogeneously than Isrecol cells in vivo. Tumor size was similar in mice injected subcutaneously, independently of the mycoplasma status (Supplementary Figure 4C). At the histological level, no major differences were observed but tumors appear to be clearly delimited by a thin fibrous and cellular capsule that showed some signs of breaching in 2/5 mycoplasma infected tumors (data not shown). However, a possible interference of mycoplasma with tumor growth can't be completely ruled out since mycoplasma are progressively cleared in vivo. Indeed no mycoplasma could be detected in cultured cells obtained from three tumors issued from mycoplasma infected cells after at least 3 week development in vivo.

\section{Co-029 molecular partners}

In order to precise the molecular connection between Co-029 and membrane receptors involved in cell motility of mycoplasma infected cells, we have used MS to identify molecules that could be closely linked to Co-029 within the tetraspanin web [6-12]. Firstly, we tried to identify surface proteins that were crosslinked to Co-029 by membrane impermeant BS3. Since cross-linked Co-029 had been observed previously at an apparent MW of $\sim 200-220 \mathrm{kDa}$ (Figure 2A) [4], we analyzed the content of the cross-linked product(s). We observed that one peptide belonging to the cdh3 domain of E-cadherin (382-GQVPENEANVVITTLK-398) and two peptides (682-LVINSGNGAVEDR-694, 716-ESSETPDQFMTADETR-731) from the cytoplasmic domain of CD44 were identified with a high score. This confirmed previous results suggesting an association between E-cadherin and Co-029 [4] and introduced CD44 as another possible Co-029 partner. The apparent MW of the crosslinked complex is higher than expected for a complex containing only E-cadherin or CD44s but it could be either a ternary complex with the 3 molecules or different complexes of Co-029 with homodimers of CD44 or E-cadherin. Subsequent MS analysis of the tetraspanins CD9 and Co-029 Brij97 complexes in Isreco1 and Isreco-Co029 cells showed the presence of 57 associated molecules, most of them already known to be present in the tetraspanin web (Table 1). Among these molecules, E-Cadherin (two peptides) and CD44 were found in both cell lines as demonstrated by their presence in cell extracts immunoprecipitated either by CD9 or by Co-029 antibodies. CD44, represented by 4 peptides (2 extracellular 79-YGFIEGHVVIPR-90 and 163-TNPEDIYPSNPTDDDVSSGSSSER-186 and the 2 peptides from the cytoplasmic domain found in crosslinking experiments), was found in the presence or absence of Co-029 in regions of the gels corresponding to the $80-90 \mathrm{kDa}$ form considered as the CD44s (standard) form and to the $120-130 \mathrm{kDa}$ form which is more likely representative of the epithelial isoform of CD44 (CD44E) containing alternative exons v9-v10 (Figure 2B). We also analyzed by MS CD44 immunoprecipitates in the presence or in the absence of Co-029. We detected previously mentioned peptides corresponding to CD44s but also peptides corresponding to alternative exons v8-v9 (498-TGPLSMTTQQSNSQ SFSTSHEGLEEDKDHPTTSTLTSSNR-537) and v10 (546-DPNHSEGSTTLLEGYTSHYPHTK-568-V10) only in cells expressing Co-029 (data not shown).

EGFR and several integrins were also found in CD9 and Co-029 immunoprecipitates but not the collagen receptors integrins $\alpha 1 \beta 1$ and $\alpha 1 \beta 2$ (a weak association of $\alpha 1 \beta 2$ was found in the CD9 immunoprecipitate). Additional MS analysis of cells cultured on tissue culture plastic were performed to determine if collagen I changed the characteristics of integrins/tetraspanins complexes obtained from cells cultured on this substrate. The label free quantification (S-Area) shows that concerning the major associated integrins (ITGA3, A6, AV, ITGB1, B4), the association is in the same order of magnitude between cells cultured on tissue culture plastic vs collagen I but unexpectedly, for ITGA3, A6 and B4, the number of identified peptides is much higher in the CD9 coimmunoprecipitations when cells are seeded on collagen I (Supplementary Table 2). For EGFR eight and nine unique peptides were identified in co-precipitates from Is1-Co029 cells by mAbs Ts9 (CD9) and Ts29.2 (Co-029) respectively and only 2 peptides by Ts9 in coprecipitates from Isreco 1 cells. Label-free quantification varied accordingly suggesting a greater association of EGFR with the tetraspanin enriched microdomains in Is1-Co029 cells Table 1.

\section{Role of EGFR on cell migration}

EGFR is detected on Isreco cells by membrane immunofluorescence (Figure 3A) and in agreement with 
MS data, we confirmed the association of EGFR with CD9 and Co-029 by western blot performed after cell lysis with Brij97 detergent (Figure 3B). However, in the presence of Co-029 the association of EGFR with the tetraspanin microdomains is increased 8 to 15 fold as shown by quantification in MS (label free) and in immunoblot. Reciprocally, Co-029 is coprecipitated with EGFR from IsCo029 cells (Figure 3C). EGFR kinase inhibitor AG-1478 (Figure 4A) or EGFR silencing (Figure 4B) or Cetuximab (a humanized monoclonal antibody that blocks EGFR) (Figure 4C), all induced an increase of cell motility of Is1Co029 cells without a detectable effect on Isreco1 cells. The motility enhancement associated with EGFR inhibition was reversed either by Co-029 silencing or by co-treatment with the Co-029 mAb Ts29.1. The increased motility of Is $1-\mathrm{Co} 029$ cells (induced by Cetuximab), as well as basal cell motility on collagen, are strongly inhibited by VLA2 RNA interference (RNAi), whereas VLA1 RNAi has only a moderate effect (Figure 4D). To explore the differential effect of EGFR inhibition on cell motility, we analysed basal EGFR phosphorylation with the anti-pY mAb 4G10. It appears that phosphorylation of EGFR in Is 1-Co029 cells is higher than in Isreco 1 cells (Figure 5A), independently of the mycoplasma status (Figure 5B), suggesting that the activation of EGFR may have an inhibitory effect on cell migration that is compensated by other mechanisms since both cell lines migrate at approximately the same speed. Since these cells have a KRAS mutation, it is supposed that the EGFR effects on cell migration are Erk independent. However, as in our previous work [4], we show a limited but significant inhibitory effect of ERK, p38 and JNK inhibitors on cell motility in cells expressing Co-029. Inhibitors of the

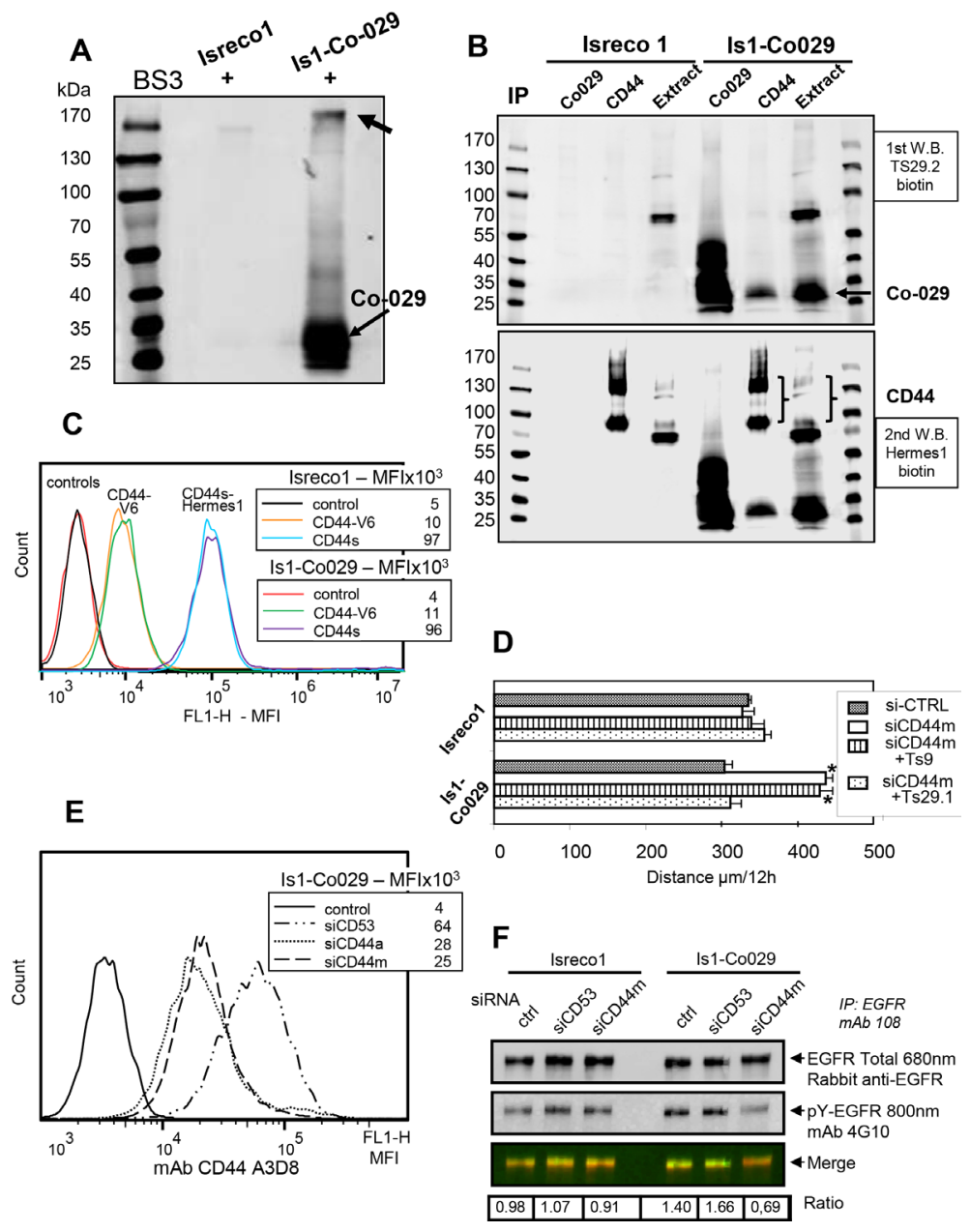

Figure 2: CD44 is associated with Co-029. (A) Crosslinking by BS3 of membrane proteins and immunoprecipitation (IP) by Ts29.1. Co-029 mAb shows by western blot the formation of a molecular complex above $170 \mathrm{kDa}$. (B) IP of Brij97 extracts shows coprecipitation of Co-029 by CD44 in Is1-Co029 cells (upper panel) whereas CD44 cannot be revealed in the Ts29.1 immunoprecipitation. (C) Expression of the CD44v6 isoform. (D) Increased motility induced by CD44 RNAi in Is1-Co029 cells that is reversed by Ts29.1 mAb and not CD9 $\mathrm{mAb}$ Ts9 (si-CD53 is used as si-CTRL). Asterisks indicates $\mathrm{p} \leq .0001$ (compared to control). (E) Efficiency of CD44 si-RNA. (F) A reduction of the ratio (arbitrary units) of pY-EGFR/total EGFR is observed upon CD44 RNAi treatment (ctr: no siRNA). EGFR was immunoprecipitated with mAb 108 and blotted with goat anti-EGFR and rabbit antigoat (680 nm) immunoglobulins followed by biotinylated 4G10 and streptavidin $800 \mathrm{~nm}$. 
Table 1: Fifty seven proteins found in the tetraspanin complexes of Isreco1 and Is1-Co029 cells after CD9 or Co-029 immunoprecipitation (IP)

\begin{tabular}{|c|c|c|c|c|c|c|c|c|c|}
\hline \multirow{3}{*}{$\begin{array}{l}\text { Proteins (genes } \\
\text { names) }\end{array}$} & \multicolumn{3}{|c|}{ Isreco1 IP CD9 } & \multicolumn{3}{|c|}{ Is1-Co029 IP CD9 } & \multicolumn{3}{|c|}{ Is1-Co029 IP Co-029 } \\
\hline & \multicolumn{2}{|c|}{ Peptides (n) } & \multirow[t]{2}{*}{ S-Area } & \multicolumn{2}{|c|}{ Peptides (n) } & \multirow[t]{2}{*}{ S-Area } & \multicolumn{2}{|c|}{ Peptides (n) } & \multirow[t]{2}{*}{ S-Area } \\
\hline & Total & Unique & & Total & Unique & & Total & Unique & \\
\hline $\begin{array}{l}\text { Co-029/ } \\
\text { TSPAN8 }\end{array}$ & NA & NA & NA & 6 & 3 & $5,64 \mathrm{E}+09$ & 6 & 4 & $1,10 \mathrm{E}+10$ \\
\hline CD9 & 11 & 6 & $1,20 \mathrm{E}+11$ & 9 & 4 & $1,63 \mathrm{E}+11$ & 10 & 4 & $9,39 \mathrm{E}+10$ \\
\hline CD81 & 5 & 3 & $7,19 \mathrm{E}+09$ & 5 & 3 & $1,79 \mathrm{E}+10$ & 5 & 3 & $9,99 \mathrm{E}+09$ \\
\hline ITGB1 & 29 & 18 & $2,72 \mathrm{E}+09$ & 28 & 17 & $3,03 \mathrm{E}+09$ & 27 & 16 & $2,43 \mathrm{E}+09$ \\
\hline EPCAM & 11 & 5 & $9,86 \mathrm{E}+08$ & 12 & 7 & $2,62 \mathrm{E}+09$ & 13 & 6 & $2,16 \mathrm{E}+09$ \\
\hline ADAM10 & 24 & 17 & $1,78 \mathrm{E}+09$ & 28 & 18 & $4,45 \mathrm{E}+09$ & 24 & 16 & $2,15 \mathrm{E}+09$ \\
\hline STX4 & 13 & 7 & $1,45 \mathrm{E}+09$ & 7 & 2 & $2,78 \mathrm{E}+09$ & 2 & 1 & $1,39 \mathrm{E}+09$ \\
\hline PLP2 & 2 & 1 & $1,47 \mathrm{E}+09$ & 1 & 1 & $2,28 \mathrm{E}+09$ & 1 & 1 & $1,25 \mathrm{E}+09$ \\
\hline SLC44A2 & 14 & 5 & $5,91 \mathrm{E}+08$ & 17 & 8 & $4,44 \mathrm{E}+09$ & 14 & 7 & $1,17 \mathrm{E}+09$ \\
\hline CD44 & 8 & 2 & $1,14 E+09$ & 9 & 5 & $5,61 E+08$ & 8 & 2 & $9,39 E+08$ \\
\hline PTGFRN & 38 & 18 & $1,52 \mathrm{E}+09$ & 38 & 18 & $3,09 \mathrm{E}+09$ & 30 & 15 & $4,52 \mathrm{E}+08$ \\
\hline BCAM & 20 & 15 & $4,54 \mathrm{E}+08$ & 22 & 11 & $4,78 \mathrm{E}+08$ & 20 & 14 & $4,35 \mathrm{E}+08$ \\
\hline ITGA3 & 23 & 14 & $1,56 \mathrm{E}+09$ & 23 & 13 & $1,89 \mathrm{E}+09$ & 19 & 10 & $4,18 \mathrm{E}+08$ \\
\hline GPR56 & 4 & 1 & $3,75 \mathrm{E}+07$ & 2 & 1 & $1,93 \mathrm{E}+08$ & 7 & 1 & $3,26 \mathrm{E}+08$ \\
\hline CD82 & 4 & 3 & $9,79 \mathrm{E}+07$ & 5 & 4 & $4,52 \mathrm{E}+08$ & 5 & 4 & $2,96 \mathrm{E}+08$ \\
\hline CYSTM1 & 2 & 1 & $1,59 \mathrm{E}+08$ & 1 & 1 & $3,46 \mathrm{E}+07$ & 1 & 1 & $2,61 \mathrm{E}+08$ \\
\hline $\mathrm{CD} 46$ & 7 & 1 & $2,02 \mathrm{E}+08$ & 5 & 1 & $4,65 \mathrm{E}+08$ & 5 & 1 & $2,50 \mathrm{E}+08$ \\
\hline LRRC59 & 10 & 6 & $2,45 \mathrm{E}+08$ & 11 & 5 & $3,20 \mathrm{E}+08$ & 10 & 3 & $2,23 \mathrm{E}+08$ \\
\hline F3 & 7 & 5 & $8,17 \mathrm{E}+08$ & 6 & 4 & $5,22 \mathrm{E}+08$ & 5 & 2 & $2,22 \mathrm{E}+08$ \\
\hline STX3 & 7 & 3 & $1,53 \mathrm{E}+08$ & 8 & 3 & $1,93 \mathrm{E}+08$ & 8 & 3 & $2,13 \mathrm{E}+08$ \\
\hline GGT1 & 6 & 3 & $3,05 \mathrm{E}+08$ & 5 & 2 & $1,79 \mathrm{E}+08$ & 5 & 1 & $2,03 \mathrm{E}+08$ \\
\hline CD63 & 1 & 1 & $1,36 \mathrm{E}+08$ & 1 & 1 & $2,87 \mathrm{E}+08$ & 4 & 1 & $1,61 \mathrm{E}+08$ \\
\hline EGFR & 2 & 2 & $1,04 \mathrm{E}+07$ & 21 & 8 & $1,41 E+08$ & 19 & 9 & $1,48 \mathrm{E}+08$ \\
\hline SLC3A2 & 10 & 3 & $3,68 \mathrm{E}+07$ & 12 & 4 & $9,96 \mathrm{E}+07$ & 18 & 7 & $1,48 \mathrm{E}+08$ \\
\hline CDCP1 & 11 & 3 & $4,73 \mathrm{E}+08$ & 19 & 8 & $5,11 \mathrm{E}+08$ & 9 & 1 & $1,42 \mathrm{E}+08$ \\
\hline TENM3 & 5 & 3 & $8,47 \mathrm{E}+07$ & 3 & 1 & $7,78 \mathrm{E}+07$ & 7 & 3 & $1,37 \mathrm{E}+08$ \\
\hline EVA1A & 3 & 2 & $5,56 \mathrm{E}+07$ & 3 & 1 & $9,38 \mathrm{E}+07$ & 2 & 1 & $1,35 \mathrm{E}+08$ \\
\hline ST14 & 12 & 6 & $1,08 \mathrm{E}+08$ & 11 & 6 & $2,10 \mathrm{E}+08$ & 3 & 1 & $1,35 \mathrm{E}+08$ \\
\hline ITGB4 & 39 & 21 & $4,28 \mathrm{E}+08$ & 30 & 19 & $4,19 \mathrm{E}+08$ & 35 & 18 & $1,25 \mathrm{E}+08$ \\
\hline NT5E & 10 & 4 & $5,20 \mathrm{E}+07$ & 12 & 6 & $6,67 \mathrm{E}+07$ & 15 & 5 & $1,25 \mathrm{E}+08$ \\
\hline GPR110 & 4 & 1 & $2,30 \mathrm{E}+07$ & 2 & 1 & $6,26 \mathrm{E}+07$ & 3 & 1 & $9,68 \mathrm{E}+07$ \\
\hline GPC1 & 2 & 1 & $1,96 \mathrm{E}+07$ & 4 & 1 & $5,88 \mathrm{E}+07$ & 6 & 3 & $8,96 \mathrm{E}+07$ \\
\hline CD97 & 7 & 3 & $5,86 \mathrm{E}+07$ & 5 & 1 & $5,70 \mathrm{E}+07$ & 7 & 6 & $8,75 E+07$ \\
\hline
\end{tabular}




\begin{tabular}{|c|c|c|c|c|c|c|c|c|c|}
\hline \multirow{3}{*}{$\begin{array}{l}\text { Proteins (genes } \\
\text { names) }\end{array}$} & \multicolumn{3}{|c|}{ Isreco1 IP CD9 } & \multicolumn{3}{|c|}{ Is1-Co029 IP CD9 } & \multicolumn{3}{|c|}{ Is1-Co029 IP Co-029 } \\
\hline & \multicolumn{2}{|c|}{ Peptides (n) } & \multirow[t]{2}{*}{ S-Area } & \multicolumn{2}{|c|}{ Peptides (n) } & \multirow[t]{2}{*}{ S-Area } & \multicolumn{2}{|c|}{ Peptides (n) } & \multirow[t]{2}{*}{ S-Area } \\
\hline & Total & Unique & & Total & Unique & & Total & Unique & \\
\hline TSPAN5 & 3 & 1 & $5,47 \mathrm{E}+07$ & 1 & 1 & $1,62 \mathrm{E}+08$ & 1 & 1 & $8,57 \mathrm{E}+07$ \\
\hline ATP1B1 & 11 & 3 & $2,98 \mathrm{E}+08$ & 6 & 2 & $1,76 \mathrm{E}+08$ & 4 & 1 & $8,51 \mathrm{E}+07$ \\
\hline ITFG3 & 1 & 1 & $2,62 \mathrm{E}+06$ & 5 & 3 & $3,21 \mathrm{E}+07$ & 7 & 4 & $8,17 \mathrm{E}+07$ \\
\hline BSG & 4 & 4 & $2,32 \mathrm{E}+07$ & 6 & 1 & $7,72 \mathrm{E}+07$ & 3 & 1 & $8,15 \mathrm{E}+07$ \\
\hline TSPAN14 & 5 & 2 & $2,79 \mathrm{E}+08$ & 10 & 4 & $7,02 \mathrm{E}+08$ & 4 & 2 & $7,97 \mathrm{E}+07$ \\
\hline ITGA6 & 33 & 15 & $4,77 \mathrm{E}+08$ & 41 & 21 & $3,50 \mathrm{E}+08$ & 29 & 12 & $7,62 \mathrm{E}+07$ \\
\hline GPR126 & 2 & 2 & $6,91 \mathrm{E}+06$ & 7 & 3 & $7,35 \mathrm{E}+07$ & 6 & 1 & $7,61 \mathrm{E}+07$ \\
\hline STX7 & 5 & 3 & $9,34 \mathrm{E}+07$ & 4 & 2 & $8,99 \mathrm{E}+07$ & 5 & 1 & $7,14 \mathrm{E}+07$ \\
\hline IGSF8 & 7 & 1 & $5,46 \mathrm{E}+08$ & 13 & 5 & $3,29 \mathrm{E}+08$ & 4 & 1 & $5,83 \mathrm{E}+07$ \\
\hline ADAM17 & 6 & 1 & $2,75 \mathrm{E}+07$ & 10 & 3 & $2,81 \mathrm{E}+08$ & 6 & 2 & $5,24 \mathrm{E}+07$ \\
\hline PCDH1 & 6 & 3 & $1,47 \mathrm{E}+07$ & 6 & 1 & $2,88 \mathrm{E}+07$ & 11 & 3 & $4,70 \mathrm{E}+07$ \\
\hline STX2 & 9 & 6 & $2,93 \mathrm{E}+07$ & 6 & 4 & $4,90 \mathrm{E}+07$ & 8 & 4 & $4,64 \mathrm{E}+07$ \\
\hline LMAN2 & 3 & 2 & $3,04 \mathrm{E}+06$ & 6 & 1 & $4,09 \mathrm{E}+07$ & 7 & 3 & $3,97 \mathrm{E}+07$ \\
\hline SDC4 & 2 & 1 & $7,79 \mathrm{E}+06$ & 1 & 1 & $1,18 \mathrm{E}+07$ & 2 & 1 & $2,46 \mathrm{E}+07$ \\
\hline ATP1B3 & 4 & 3 & $8,39 \mathrm{E}+07$ & 5 & 3 & $4,55 \mathrm{E}+07$ & 2 & 1 & $2,43 \mathrm{E}+07$ \\
\hline SLC44A1 & 9 & 7 & $5,25 \mathrm{E}+07$ & 10 & 5 & $2,04 \mathrm{E}+08$ & 2 & 1 & $2,26 \mathrm{E}+07$ \\
\hline PLAUR & 3 & 1 & $3,22 \mathrm{E}+07$ & 4 & 1 & $3,84 \mathrm{E}+07$ & 3 & 2 & $1,68 \mathrm{E}+07$ \\
\hline HLAcII & 2 & 3 & $1,33 \mathrm{E}+07$ & 1 & 4 & $2,51 \mathrm{E}+07$ & 3 & 4 & $1,61 \mathrm{E}+07$ \\
\hline CLDN1 & 2 & 1 & $1,91 \mathrm{E}+07$ & 2 & 1 & $1,50 \mathrm{E}+07$ & 2 & 1 & $1,46 \mathrm{E}+07$ \\
\hline PLSCR3 & 1 & 1 & $1,51 \mathrm{E}+07$ & 1 & 1 & $1,16 \mathrm{E}+07$ & 3 & 1 & $1,42 \mathrm{E}+07$ \\
\hline L1CAM & 18 & 6 & $5,79 \mathrm{E}+07$ & 5 & 1 & $6,11 \mathrm{E}+06$ & 10 & 3 & $1,17 \mathrm{E}+07$ \\
\hline LDLR & 5 & 4 & $5,08 \mathrm{E}+06$ & 4 & 2 & $1,32 \mathrm{E}+07$ & 4 & 2 & $1,09 \mathrm{E}+07$ \\
\hline CDH1 & 4 & 2 & $2,25 \mathrm{E}+07$ & 3 & 1 & $1,38 E+07$ & 2 & 1 & $8,10 \mathrm{E}+06$ \\
\hline MCAM & 12 & 7 & $3,38 \mathrm{E}+07$ & 3 & 1 & $8,78 \mathrm{E}+06$ & 1 & 1 & $5,69 \mathrm{E}+06$ \\
\hline NOTCH2 & 5 & 1 & $7,98 \mathrm{E}+06$ & 3 & 1 & $1,30 \mathrm{E}+07$ & 5 & 3 & $5,07 \mathrm{E}+06$ \\
\hline
\end{tabular}

MS identification of membrane proteins (GPI anchor and single or multipass membrane proteins) associated to CD9 and Co-029 after IP by Ts9 (CD9) or TS29.2 (Co-029) mAbs of Brij97 extracts from Isreco 1 and Is1-Co029 cells cultured on collagen. Proteins were ordered by decreasing label free quantitation of identified proteins in Is1-Co029 Ts29.2 IP. Co-029 found only in Is1-Co09 cells was added for information. Proteins studied in this article are indicated in bold.

MAPKinases pathways also impaired the stimulatory effect of Cetuximab and reduced the migration of Cetuximab treated cells below basal level values (Figure 5C). A similar but less pronounced effect was obtained by Akt inhibition (Figure 5C). Interestingly, it was possible to substitute the effect of mycoplasma on cell motility by HGF addition (Figure 5D), whereas EGF had no effect (not shown). As for mycoplasma infected cells, Cetuximab increased only the motility of Co-029 expressing cells. Cells were completely stopped by Rac1 RNAi.

\section{Role of CD44 on cell migration}

Western blots of cell extracts or immunoprecipitates of CD44 showed 2 major isoforms at $80-90$ and $130 \mathrm{kDa}$ and other forms with higher apparent MW (Figure 2B). We confirmed CD44/Co-029 association by immunoblot performed after cell lysis with Brij97 detergent and coimmunoprecipitation. Since Co-029 association was observed by immunoblot in the CD44 immunoprecipitation but not in the reverse precipitation, it precluded the observation of a preferential association of Co-029 with 
a specific isoform of CD44 (Figure 2B) such as CD44v6. CD44v6 was expressed at the same level in Isreco cell lines independently of the expression of Co-029 (Figure 2C).

The association between Co-029 and CD44 may be functionally relevant since CD44 RNAi (Figure 2D2E) induced an increased motility of Is $1-\mathrm{Co} 029$ cells, reversed by the anti Co-029 mAb Ts29.1, whereas no effect of CD44 RNAi was found in the Isreco1 cell line (Figure 2D). We investigated whether CD44 effect could be mediated through an interaction with EGFR by measuring EGFR phosphorylation in CD44 siRNA treated cells. Reduction of CD44 expression was accompanied by a $>50 \%$ reduction of EGFR phosphorylation specifically in Is 1-Co029 cells (Figure 2F).

\section{DISCUSSION}

In this work we demonstrate that the migration on collagen I of colorectal carcinoma cells Isrecol and its Co029 transduced counterpart, Is1-Co029, is a complex and multistep event with differences linked to the expression of Co-029. In both types of cell lines, a double signal is

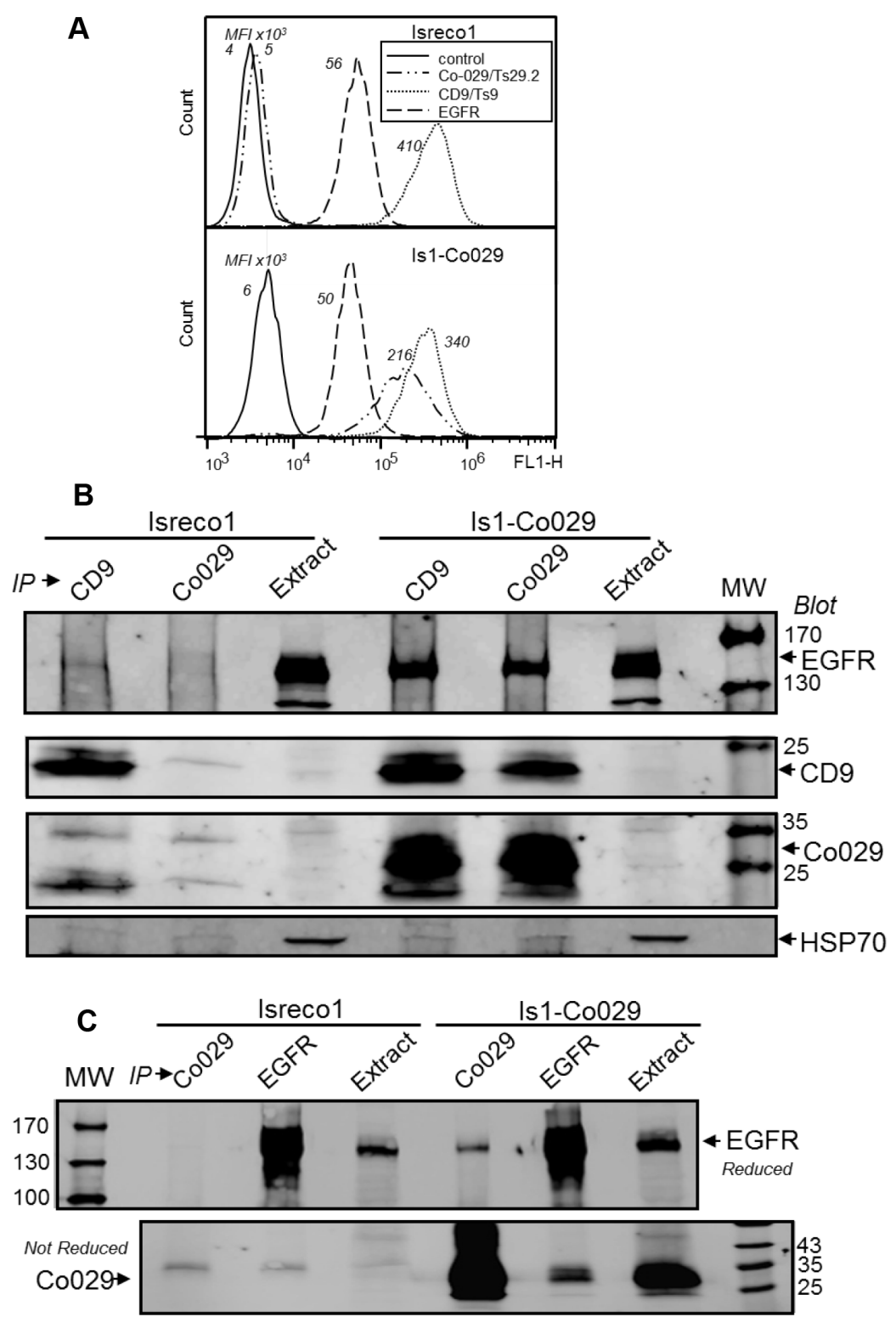

Figure 3: Co-029 increases the association of EGFR with the tetraspanin web. (A) Co-029, CD9 and EGFR flow cytometry profiles of Isreco1 cells and Co-029 transduced cell line Is1-Co029. Mean fluorescence intensity (M.F.I.) values are indicated. Background represents the signal detected with a negative control mAb. The level of EGFR is similar in the two cell lines. (B) The presence of Co-029 increases the association of EGFR with the tetraspanin web as shown by the clear co-precipitation of EGFR with CD9 and Co-029 in Is1Co029 cells whereas only a weak co-precipitation with CD9 is seen in Isreco1 cells. (C) Immunoprecipitation of EGFR by mAb 108 shows the reciprocal association of Co-029 with EGFR. 
required for induction of motility analyzed at single cell level. Collagen I triggers a signal mediated by $\beta 1$ integrins involving the collagen receptors $\alpha 1$ and $\alpha 2$ [4], whereas a $2^{\text {nd }}$ signal mediated by MyD88 is necessary. This signal appears to be triggered by mycoplasma in contaminated cells and can be substituted by PGN, a TLR2 ligand, in mycoplasma free cells. A second level of control over cell motility is exerted by Co-029 through different membrane receptors. In a previous work, we already showed that when Co-029 is expressed, the speed is controlled by the E-cadherin/p120ctn complex since silencing of these proteins increases the speed of the cells. In this work we also show that when Co-029 is expressed, EGFR or CD44 inhibition increases cell motility.

If the involvement of viruses and bacteria has been widely recognized as key event for the development of several types of tumors, the role of mycoplasma has been more rarely addressed. This class of bacteria that lacks a cell wall has the particularity to grow in close relationship with mammalian cells apparently for unlimited time and without major changes in cell aspect. For biologists, mycoplasmas are generally considered as a drawback in experiments dealing with cell cultures since they can interfere with multiple parameters that may influence
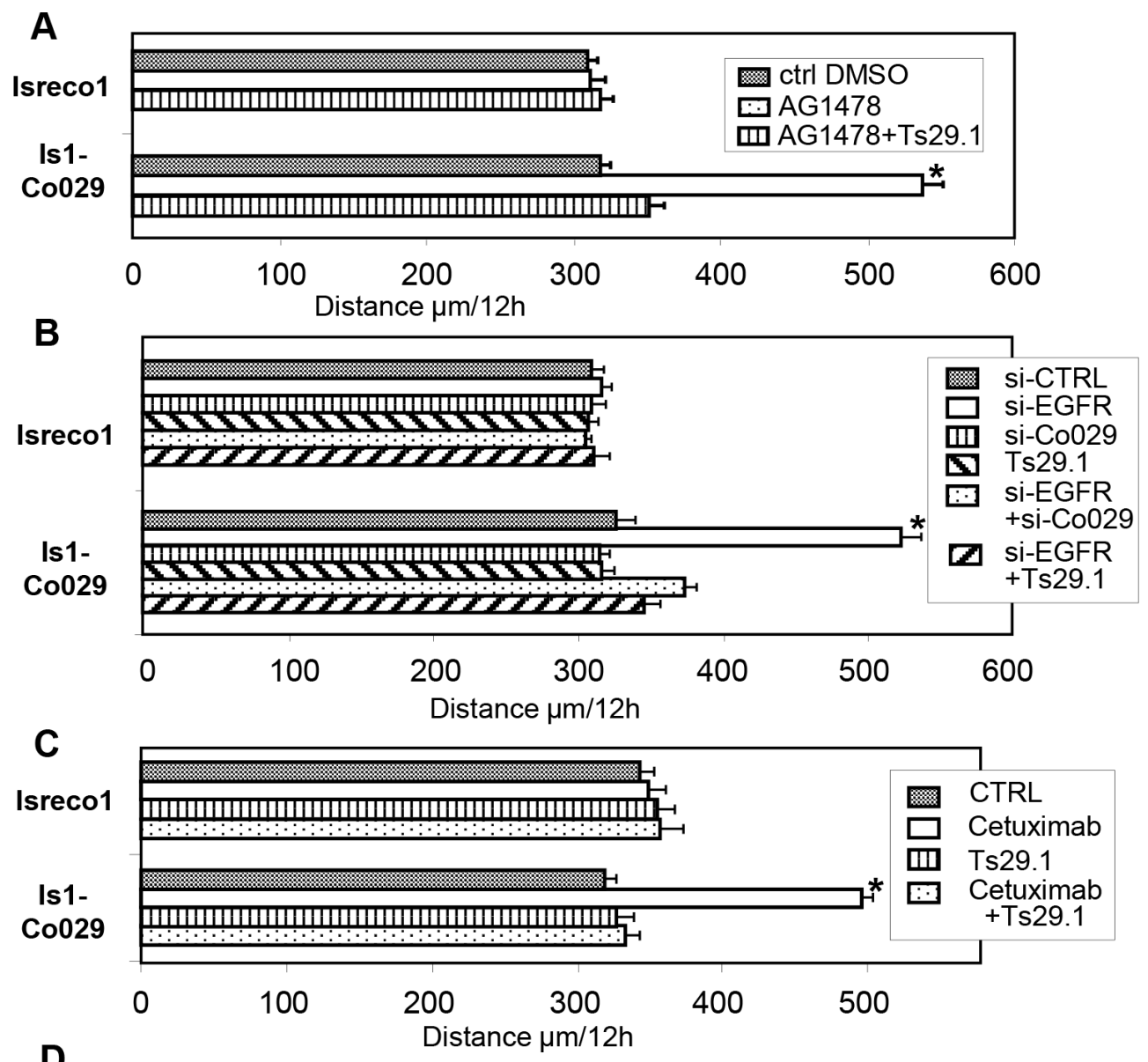

D

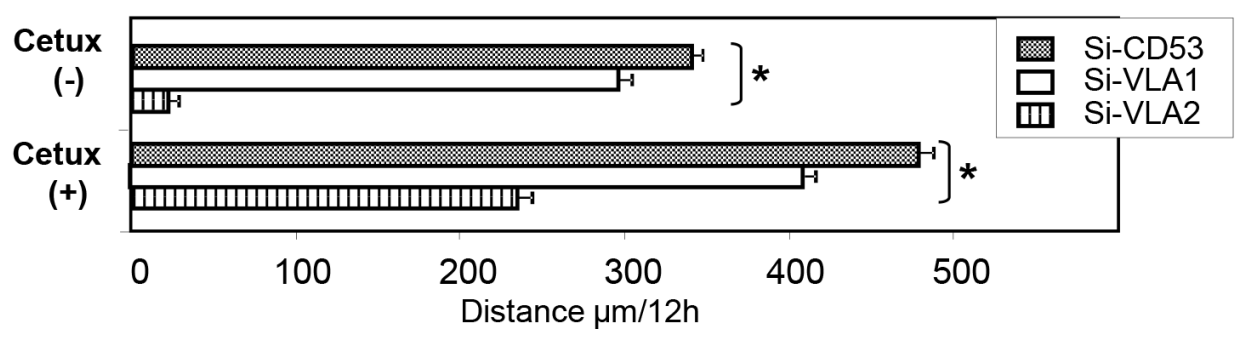

Figure 4: The effect of EGFR on cell motility is related to Co-029 expression. (A) Increased motility of Is1-Co029 cells induced by chemical inhibitor of EGFR, AG1478, (B) by silencing of EGFR, and reversion by Co-029 silencing or addition of the Co-029 $\mathrm{mAb}$ Ts29.1 (for si-CTRL = siCD53). (C) Increased motility induced by Cetuximab and reversion by addition of the Co-029 $\mathrm{mAb}$ Ts29.1. (D) Inhibition of Is1-Co029 cell motility by integrins VLA1 and VLA2 RNAi. Asterisks indicates $\mathrm{p} \leq .0001$. 
A
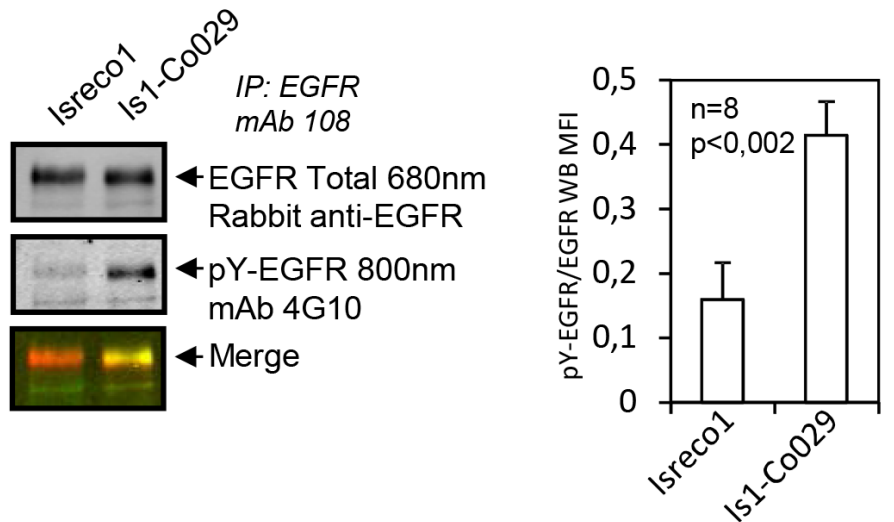

B

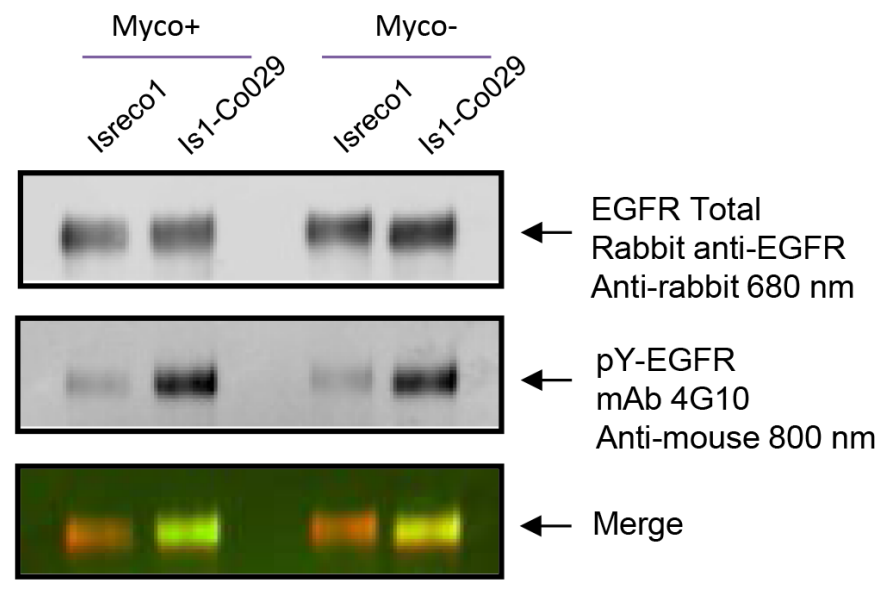

C

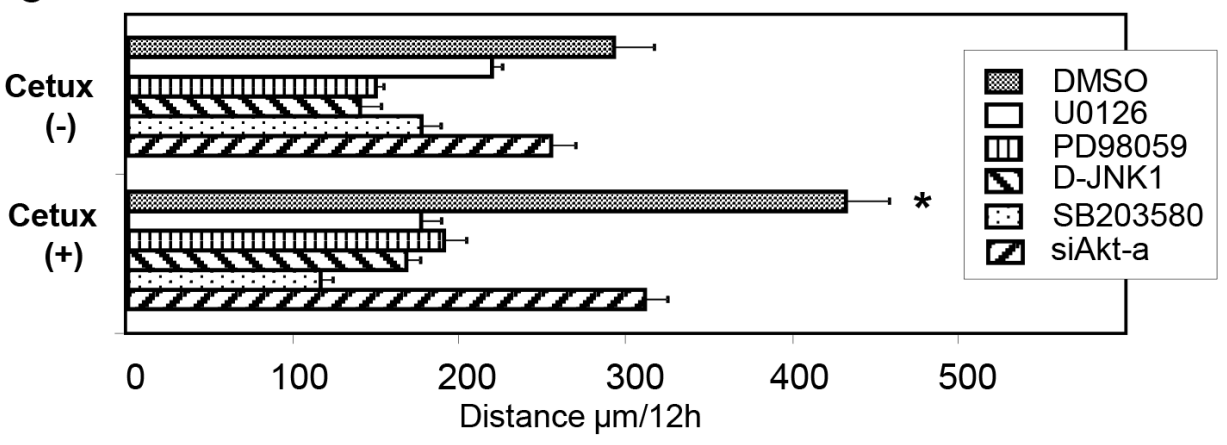

D

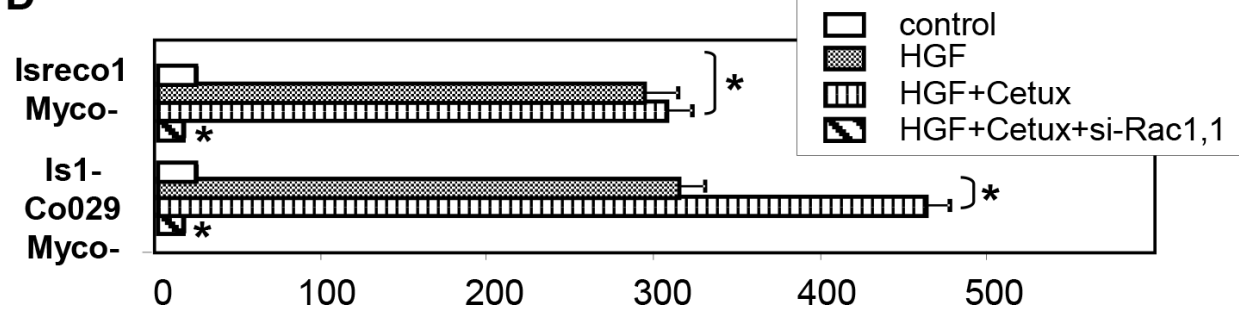

Figure 5: EGFR phosphorylation and signalling pathways. (A) Basal tyrosine phosphorylation of EGFR is increased in Is1Co029 cells as shown by repeated $(n=8)$ immunoprecipitations of EGFR and labelling of pY by mAb 4G10. (B) Increased phosphorylation of EGFR upon Co-029 expression is independent of mycoplasma status. (C) The chemical MAPK inhibitors and Akt RNAi reversed the acceleration of Is1-Co029 cells induced by Cetuximab. (D) HGF triggers cell migration of Myco- cells on collagen I. Effect of Cetuximab and Rac1 RNAi (si-Rac1.1). All tests (except for si-Rac1.1) were performed with control si-RNA (si-CD53). Asterisks indicates $\mathrm{p} \leq 0001$. 
results of experimental investigations. For that reason, it is generally requested to work with mycoplasma free cells and several types of antibiotics are able to clear the cells with varying efficiency. However, the effect of mycoplasmas derived molecules on migration and invasion of normal or malignant cells has already been suggested by some experimental data. Several studies have reported that mycoplasma infection could increase tumor cell invasiveness [15], and the presence of Mycoplasma hyorhinis protein $\mathrm{p} 37$ and Mycoplasma DNA in more than $50 \%$ of human cancer tissues including ovarian, gastric, colon carcinomas, esophageal, lung or breast cancer vs less than $25 \%$ of benign digestive lesions indicates the frequent coexistence of mycoplasma and tumor in vivo [16]. Mycoplasma may enhance the malignant phenotype in prostate and melanoma cancer cells through increased invasion and migration potential [17]. A role for the mycoplasma protein $\mathrm{p} 37$ has been shown by neutralization with the corresponding antibody [17]. Even a direct role of mycoplasma in cell transformation has been inferred from cultures of benign human prostate cells (BPH1) infected with M. genitalium or M. hyorhinis that led to the acquisition of a malignant phenotype with anchorage independent growth, increased migration and invasion [18]. These phenotypic alterations were associated with the acquisition of chromosomal aberrations. A statistically significant association between $\mathrm{M}$. hominis infection and human prostate cancer has been reported [19-21]. In the neuroblastoma cells SH-SY5Y, an upregulation of calpastatin was reported to result in the inhibition of calpain, a proteolytic enzyme involved in many biological processes including migration [22]. Accordingly, the phenotypic alterations induced by mycoplasmas could be viewed as tumor promoting events or even as tumorigenic.

Results in our model demonstrate that mycoplasma have a direct triggering effect on cell migration and that this effect is mediated by TLR2. Physiologically, epithelial cells are continuously exposed to pathogens for which they have developed defense mechanisms in order to maintain the integrity of the tissue barrier [23]. They express different pattern recognition receptors as TLR or Nod that upon ligand binding and corresponding signalization lead to the production of host defense molecules. In addition TLR2 and 5 signaling may induce epithelial repair and survival independently of inflammatory cells or mediators [24]. Through their ability to activate the adaptive immune system, TLR may act as negative regulators of tumors. On the other hand, a direct effect of TLR ligands may promote tumor survival and growth in vitro and in vivo (for review see [25]). For instance the endogenous ligand versican may activate the TLR2 pathway [26]. Whether the ability of mycoplasmas to trigger cell migration in vitro, observed in the present report, could be viewed as rendering tumor cells more invasive and aggressive in in vivo situations is not supported by tumor growth in subcutaneously injected nude mice. However the absence of differential growth after subcutaneous implantation of mycoplasma infected or mycoplasma free cells may be explained by the observation that infected cells are cleared from mycoplasma in vivo.

Another level of regulation in the mechanisms of migration of Isrecol cells is added by the stimulatory effects of inhibitors of EGFR only in cells expressing the tetraspanin Co-029. In this multiparameter control of motility, it is interesting to observe that the tetraspanin Co029 seems to connect EGFR with the signaling pathways involved in the dual Integrin/TLR induced cell motility since silencing of EGFR accelerates migration of Co-029/ tspan8 expressing cells.

In an effort to find a link between modulation of cell motility and Co-029 expression we undertook an extensive MS analysis of Co-029 associated molecules. We compared data obtained from chemical crosslinking experiments that identify primary partners with those issued from immunoprecipitation of Brij97 extracts that harvest higher order complexes (tetraspanin web). In addition to E-cadherin, crosslinking suggests that Co-029 associates with CD44 but in a non-exclusive way since CD44 is found in the tetraspanin web (Brij97 extracts) also in the absence of Co-029. CD44 is a very complex surface molecule due to its multiple spliced isoforms and heavy glycosylation. Its extra- and intracellular domains are known to interfere with numerous molecules particularly after fixation of hyaluronate. CD44 is associated with major cell functions like adhesion, motility, proliferation, stemness and is, as such, an actor of the tumor phenotype [27]. Among CD44 functionally interacting molecules, RTK, matrix proteinases and ERM are noticeable and could represent a link between cell motility and Co-029 expression.

Concerning the association of Co-029 with EGFR, MS analysis and western blots of Brij97 extracts immunoprecipitated with Ts9 (CD9) and Ts29.2 (Co029) clearly show an increased association of EGFR with the tetraspanin web in the presence of Co-029. To our knowledge, it is the first time that the association of EGFR to the tetraspanin web was shown using the detergent Brij97 that is much more stringent than Brij98 or Chaps used in previous studies [28-30]. However, since EGFR was not crosslinked to $\mathrm{Co}-029$ by $\mathrm{BS} 3$, a direct interaction is not proven.

The increased motility induced by the inhibitor AG1478 and by siRNA, directed against EGFR, is reproduced by a function blocking antibody, suggesting that EGFR's signal in Co-029 expressing cells may occur through an autocrine stimulation pathway. Indeed, increased phosphorylation of EGFR in Is1-Co029 cells compared to Isrecol cells indicates an activation (or transactivation) of EGFR. The case of EGFR is particular since the mutation of KRAS should result in constitutive stimulation of the Erk1/2 pathway, rendering these cells resistant to EGFR issued signals. Our results show an unanticipated effect 
of silencing or functional blocking of EGFR that activates cell migration, indicating that in this configuration (constitutive activation of the Erk1/2 pathway), with the cooperation of Co-029, EGFR signaling may act as a brake of cell migration, possibly by Erk $1 / 2$ induced negative feedbacks [31].

The control of RTK signaling by the tetraspanin web has been reviewed extensively recently [32, 33]. Depending on the cell type and the tetraspanin tested, different effects may be observed, for instance CD151 enhances ErbB2 signaling [34], whereas CD82 attenuates EGFR signaling $[28,35,36]$. CD82 expression in several cell lines has been shown to modify signaling events downstream of integrins and EGFR [28, 35, 36]. A functional interaction between CD9 and $\alpha 2 \beta 1$ integrin has also been reported [37].

More generally, crosstalk between integrins and RTK signaling pathways has been largely documented in the literature [38]. This crosstalk may vary between different cell types but in certain cells, a significant fraction of integrin signaling may be mediated by RTK transactivation. Furthermore, the EGF induced phosphorylation of EGFR is potentiated by integrinmediated adhesion but diminished by the integrin interacting tetraspanin CD151 [28, 36, 39].

On the whole, crosstalk involving tetraspanins may start at the membrane level through interactions within the tetraspanin web but also downstream, along signaling pathways that are differentially connected/activated according to membrane organization and signals issued from the microenvironment

In Is1-Co029 cells, we have shown that the expression of Co-029 is dramatically involved for regulation of $2 \mathrm{D}$ cell migration through E-cadherin/ p120catenin [4], EGFR or CD44. On the contrary, in Isrecol cells, these molecules do not seem to be involved in the regulation of basal cell migration, at least within the limits of this methodology. An explanation could be proposed in view of the hierarchical organization of the tetraspanins web in which the presence of Co- 029 would preferentially interconnects adhesion receptors and RTK signaling pathways to drivers of cell migration such as TLR2 and integrins, possibly through the multifaceted molecule CD44. This interpretation remains compatible with the nanocluster organization of tetraspanin/partners complexes visualized by super-resolution microscopy [40] that challenges the view of the microdomains based organization of the tetraspanin web. If in this example Co-029 serves as an integrator of signals regulating cell migration, it may explain why and how different cell types may respond differently to similar stimuli since this tetraspanin has a restricted tissue expression and its expression varies between tumors of same tissue origin. A limit to the interpretation of the data is the $2 \mathrm{D}$ in vitro model of cell migration used in this work that may not be representative of in vivo tumor cell migration in which 3D migration and multiple molecular substrates introduce different parameters. Finally, since biological effects linked to the modulation of adherence molecules or RTK may be reversed by Co- 029 antibodies, this points to possible mechanisms of the in vivo efficiency of these antibodies in experimental models [41, 42].

\section{MATERIALS AND METHODS}

\section{Cell lines}

The cell line Isrecol was initially derived from a primary human colon cancer (Duke's C, class III) surgical specimen [43]. These cells, transferred to our laboratory in 2002 by Dr. B. Sordat at ISREC, Lausanne, were cultured in Dulbecco's modified Eagle's medium (DMEM) supplemented with 10\% FCS, glutamax and antibiotics (all from Invitrogen). For experiments, tissue culture plastics were coated with rat tail collagen I (BD Biosciences) for 1 hour at $50 \mu \mathrm{g} / \mathrm{ml}$ and rinsed with PBS. Isrecol cells were transduced to express the tetraspanin Co-029. Non cloned cell lines were used for these experiments and are called Is1-Co029 [4]. Phenotypic characteristics of the Isreco cell lines (morphology and surface markers) were reported previously [10]; they are checked after each thawing and before a set of experiments to avoid contamination between cell lines. To determine the mutational status of the cells we used OncoCarta ${ }^{\mathrm{TM}}$ Panel v1.0 from Sequenom with the MassARRAY system. The Isreco1 and Co-029 transduced cells harboured a G12D homozygous mutation of KRAS whereas no mutations of BRAF and PI3K were found. The cell lines were further characterized by transcriptomal analysis (Miltenyi Biotech Microarray Service, Bergisch Gladbach, Germany) using Agilent Whole Genome Oligo Microarrays (4x44K one color). For in vivo studies, we used the SW480 cells (ATCC) that were checked for the homozygous G12V mutation before use.

\section{Mycoplasma detection}

Mycoplasma infection was searched by using the Mycoplasma Detection Kit MycoAlert ${ }^{\circledR}$ (Lonza) which detects the presence of ATP in the supernatant.

\section{Antibodies}

The anti-tetraspanin mAb Ts9 against CD9, Ts29.1(IgG1) and Ts29.2(IgG2b) directed against Co-029 used in this study were produced in our laboratory [4]. The following commercial antibodies were purchased: anti p65-NFkB (Goat IgG and mouse monoclonal, SantaCruz), anti EGFR (1005) (Rabbit IgG, Santa-Cruz), anti EGFR Cetuximab (Merck Serono), anti EGFR mAb108 (ATCC), monoclonal biotinylated anti CD44 156-3C11 (Thermo Scientific), monoclonal anti CD44 Hermes-1 
(rat, Thermo Scientific), monoclonal anti CD44v6 VVF8 (Mouse, Abcam), anti-Cytokeratin 8 and 18, antiVimentin (Invitrogen, France). These antibodies were used as primary antibodies for immunoprecipitation, immunoblotting, immunostaining or functional studies.

\section{Immunofluorescence}

For flow cytometry analysis of cell surface molecules, cells were detached using a non-enzymatic solution (Invitrogen), washed and stained with $10 \mu \mathrm{g} / \mathrm{ml}$ of primary antibody. After washes in culture medium, cells were incubated with $10 \mu \mathrm{g} / \mathrm{ml}-1$ FITC-labelled secondary antibody (Beckman Coulter), washed again three times and fixed with $1 \%$ formaldehyde in PBS. All incubations were performed for $30 \mathrm{~min}$ at $4^{\circ} \mathrm{C}$. Analysis of cellsurface staining was performed using a FACScalibur flow cytometer (Becton-Dickinson, San Jose, CA, USA).

For intracellular cytometry, cells were detached using trypsin or scrapped in $\mathrm{PBS}\left(4^{\circ} \mathrm{C}\right)$ then fixed for $20 \mathrm{~min}$ at $4^{\circ} \mathrm{C}$ with $1 \%$ formaldehyde in PBS. After centrifugation, cells were incubated in methanol $100 \%$ for $10 \mathrm{~min}$ at $-20^{\circ} \mathrm{C}$ then washed in PBS and stained with $10 \mu \mathrm{g} / \mathrm{ml}$ of primary antibody. After washes in PBS, cells were incubated with $10 \mu \mathrm{g} \mathrm{ml} \mathrm{FITC-labelled} \mathrm{secondary}$ antibody (Beckman Coulter), washed again three times and immediately analysed.

For in-situ labelling of p65-NFkB (Goat IgG, Santa-Cruz), cells cultured in labtek chambers were immunostained by fixing with $4 \%$ formaldehyde for 10 min followed by permeabilization with Triton X100 at 1\% for $10 \mathrm{~min}$. Incubation was performed in the chambers with first antibodies at $10 \mu \mathrm{g} / \mathrm{ml}$ followed by appropriate fluorochrome coupled $2^{\text {nd }}$ antibodies. For CK8/18 and vimentin labelling, cells were fixed with ice-cold methanol for $10 \mathrm{~min}$ followed by PBS rinsing and drying for $30 \mathrm{~min}$.

\section{Immunoprecipitation, western blot and crosslinking}

Cells were lysed directly in the tissue culture flask (2 $\mathrm{ml}$ for a $150-\mathrm{cm} 2$ flask) in lysis buffer (10 mM Tris ( $\mathrm{pH}$ 7.4), $150 \mathrm{mM} \mathrm{NaCl}, 0.02 \% \mathrm{NaN} 3,1 \mathrm{mM}$ phenylmethylsulfonyl fluoride, $0.5 \mathrm{mg} / \mathrm{ml}$ leupeptin, 1 $\mathrm{mg} / \mathrm{ml}$ pepstatin A and 10 kallikrein-inactivating units/ $\mathrm{ml}$ aprotinin) containing 1\% Brij97 (Roche Molecular Biochemicals, Meylan, France). After a 30-min incubation at $4^{\circ} \mathrm{C}$, the insoluble material was removed by centrifugation at 10,000 $\mathrm{g}$ and the cell lysate was precleared overnight by addition of 0.005 volume of heat-inactivated goat serum and 0.025 volume of protein G-Sepharose beads (Amersham Pharmacia Biotech). Proteins were then immunoprecipitated by adding $2 \mu \mathrm{g} / \mathrm{ml}$ of antibodies and $30 \mu \mathrm{l}$ of protein G-Sepharose beads to $1 \mathrm{ml}$ of the lysate. After a 2 hour incubation at $4{ }^{\circ} \mathrm{C}$ under constant agitation, the beads were washed five times in lysis buffer. The immunoprecipitates were then separated by $5-15 \%$
SDS-polyacrylamide gel electrophoresis usually under nonreducing conditions (or after reduction of the samples when appropriate) and transferred to a PVDF membrane (Amersham Pharmacia Biotech). Western blotting on immunoprecipitates was performed using biotinylated mAbs and a Alexa Fluor 680-labelled streptavidin (Invitrogen) which was revealed with the Odyssey Infrared Imaging System (LI-COR Biosciences). Alternatively, for unlabelled primary antibodies, secondary reagents labelled with Alexa Fluor 680 or $800 \mathrm{~nm}$ were used. For crosslinking, the cells were incubated for $30 \mathrm{~min}$ at $4{ }^{\circ} \mathrm{C}$ in the culture flask with $0.7 \mathrm{mM}$ of water soluble BS3 (Pierce, Rockford, IL) in PBS 1X. They were washed three times in PBS $1 \mathrm{X}$ before lysis in 1\% Triton $\mathrm{X}-100$ lysis buffer at $4{ }^{\circ} \mathrm{C}$ and immunoprecipitation. For detection of protein tyrosine phosphorylation, the lysis buffer contained $1 \%$ Triton X-100, $50 \mathrm{mM}$ tris $\mathrm{pH} 8,150 \mathrm{mM} \mathrm{NaCl}, 1 \mathrm{mM}$ EDTA, $0.02 \% \mathrm{NaN}_{3}, 1 \mathrm{mM}$ sodium orthovanadate, $10 \mathrm{mM}$ $\mathrm{NaF}$ and proteases inhibitors. Protein phosphorylation was detected using the anti-phosphotyrosine mAb 4G10 (Upstate Biotechnology).

For subcellular detection of NFkB, a subcellular protein fractionation kit was used (Pierce Scientific, Rockford, USA).

\section{RNA silencing}

Cells $\left(1-3 \times 10^{5}\right.$ cells in DMEM medium) were reverse transfected with synthetic si-RNA oligonucleotides using Interferin (Ozyme) according to manufacturer's protocol.

6,12 or 24 well cell culture plates were coated with rat tail collagen I. Plates were rinsed in PBS. To allow formation of the transfection complexes a mix of 3-5 $\mu \mathrm{l}$ of interferin, $1 \mu \mathrm{l}$ of siRNA $(10 \mu \mathrm{M})$ and $96 \mu \mathrm{l}$ of free DMEM was added to each well and incubated at room temperature during $20 \mathrm{~min}$ to allow formation of transfection complexes. After detachment by trypsinEDTA, cells were layered at appropriate concentration in $400 \mu 1$ DMEM medium with serum (the final concentration of siRNA was $20 \mathrm{nM}$ ).

Sequences of siRNA were either obtained from the literature or chosen according to reported criteria. Only sequences allowing inhibition of at least $75 \%$ protein expression in our system were retained for the study and are listed below. The following siRNA were synthetized by Eurogentec unless specified.

The si-RNA labelled with an asterisk were used throughout the study, the other si-RNA served as controls for specificity of the biological effects.

*si-CD53 GGAAAACAAGUGUCUGCUUdTdT

*si-Co029 GGUAUCCUAGGAGCUGUUUdTdT

(see [4])

*si-EGFR CUCUGGAGGAAAAGAAAGUdTdT si-VLA2-952D

ACGCCCUUGAUACUAAAAAdTdT (see [4]) 


\author{
*si-VLA2-994D \\ UCGCUAGUAUUCCAACAGAdTdT (see [4]) \\ *si-VLA1-280D \\ AGUUGGAUCUACCAGUUAAdTdT (see [4]) \\ si-VLA1-171D \\ GAAGGAAAAUGGGUGCUUAdTdT (see [4]) \\ si-VLA1-1286D \\ UGAACCGCUUGCUUCUUAUdTdT (see [4]) \\ *si-Vav2.2 AGUCCGGUCCAUAGUCAACdTdT \\ [44] \\ Si-Vav2.3 CAACAAGGACGUCAAGAAdTdT \\ [44] \\ *si-Rac1.1 AGACGGAGCUGUAGGUAAAdTdT \\ si-Rac1.2 UAAGGAGAUUGGUGCUGUdTdT \\ * si-MyD88a \\ AAGGAAUGUGACUUCCAGACCdTdT \\ (Communicated by Katy Le Corf, Lyon) \\ si-MyD88b \\ GGAAUGUGACUUCCAGACCUUdTdT [45] \\ si-TLR2b GACUUAUCCUAUAAUUACdTdT [46] \\ si-CD44a UAUUCCACGUGGAGAAAAAdTdT \\ si-CD44m SMARTpool ON-TARGETplus siRNA \\ (Dharmacon) \\ si-Akt-a UGCCCUUCUACAACCAGGAdTdT \\ (targeting Akt1 and Akt2) [48] (see [4] for efficiency) \\ Stealth si-RNA for Co-029 and TLR2 were also \\ purchased from Invitrogen (Carlsbad, California) \\ si-Co029s 789 \\ CCUGAAUUAUGUGCCUGUCUAGAUA (see [4]) \\ *si-TLR2s \\ UGAAGCAUCAAUCUCAAGUUCCUCA [49]
}

For motility measures, RNAi treatments were performed 48 hours before videomicroscopy. Experiments were repeated from 2 to 10 times to verify the robustness of the results and the stability of the measurements.

\section{QRT-PCR}

Total RNA was purified using TRIzol reagent (Invitrogen). First, the purified RNAs were treated with DNase (Qiagen) in order to remove possible contamination with genomic DNA. Digestion was realized at $37^{\circ} \mathrm{C}$ for $15 \mathrm{~min}$ in presence of $5 \mathrm{mM} \mathrm{MgCl} 2$ and then the enzyme was inactivated at $75^{\circ} \mathrm{C}$ for $10 \mathrm{~min}$. RT was performed in triplicate using the Taqman Reverse Transcription Reagents kit purchased from Applied Biosystems: $1 \mu \mathrm{g}$ of total RNA was added in a final volume of $45 \mu \mathrm{l}$ containing 1x RT buffer, $1 \mathrm{mM}$ dNTPs, $0.44 \mathrm{Unit} / \mu \mathrm{l}$ of RNase inhibitor, $1 \mu \mathrm{M}$ random hexamers and 1.25 unit/ $\mu \mathrm{l}$ of MultiScrib reverse transcriptase. After incubation at $37^{\circ} \mathrm{C}$ for $60 \mathrm{~min}$, the samples were heated for $5 \mathrm{~min}$ at $95^{\circ} \mathrm{C}$ to end the reaction and stored at $-20^{\circ} \mathrm{C}$ till PCR use. cDNA $(2 \mu \mathrm{l})$ was subjected to real-time quantitative PCR using the MXPro system with Brilliant II SYBR Green QPCR MasterMix (Agilent Technologies). PCR reactions were performed for each sample and the average threshold cycle number was determined using the Mx3005P v4.10 software. Levels of specific mRNA and expressions normalized to RPL38 levels were determined using the formula $2^{\text {(Rt-Et) }}$ where $\mathrm{Rt}$ is the threshold cycle for the reference gene (RPL38), and Et is the threshold cycle for the experimental gene ( $\triangle \Delta \mathrm{CT}$ method). Data are thus expressed as arbitrary units. Sequences of primers used: Snail (F: 5'-CCTCCCTGTCAGATGAGGAC-3', R: 5'-CC AGGCTGAGGTATTCCTIG-3'), Twist (F: 5'-GGA GTCCGCAGTCTTACGAG-3', R: 5'-TCTGGAGGACC TGGTAGAGG-3'), Zeb2 (F: 5'-TTCCTGGGCTACG ACCATAC-3', R: 5'-TGTGCTCCATCAAGCAATTC-3'), Slug (F: 5'-GGGGAGAAGCCTTTTTCTTG-3', R: 5'-TCCTCATGTTTGTGCAGGAG-3').

\section{Videomicroscopy}

Analysis of 2D cell motility on collagen I films was performed using phase contrast on an inverted microscope (Axiovert 200; Zeiss, Oberkochen, Germany) equipped with an environmental chamber with $5 \% \mathrm{CO} 2$ at $37^{\circ} \mathrm{C}$. Cells were seeded in 24 well plates (5000 cells/well) in DMEM supplemented with $10 \%$ FCS, glutamax and antibiotics. The microscope was driven by the Metamorph software (Roper Scientific) and images were recorded with a Coolsnap HQ camera (Roper Scientific). Stacks of phase contrast images were collected every $15 \mathrm{~min}$ for $24 \mathrm{~h}$ at x200 magnification. Cell migration was quantified using the manual tracking plugin of ImageJ [50]. Raw data were transferred to Excel for speed calculations and statistical analysis was performed by the non-parametric Mann-Whitney test in Graphpad. For each position at least 10 cells were analyzed. In addition to various siRNA, Cetuximab $(25 \mu \mathrm{g} / \mathrm{ml})$, the EGFR inhibitor AG1478 (Merck, Germany) at 5 $\mathrm{M}$, PD98059 for Mek1 $(20 \mu \mathrm{M}), \mathrm{U} 0126$ (Promega) at $10 \mu \mathrm{M}$ for the MAPK Erk, SB203580 (Calbiochem) at $20 \mathrm{nM}$ for the MAPK p38, D-JNKI-1 targeting JNK1 (a gift of Xigen SA) at $3 \mu \mathrm{M}$ were used in motility experiments as well as the TLR2 ligand B. subtilis peptidoglycan, PGN (InvivoGen, San Diego).

\section{In vivo experiments}

Balb/c nude mice were injected with $5.10^{6} \mathrm{SW} 480$ tumor cells subcutaneously in the back on day 0. Mice were divided in two groups which were injected either with mycoplasma infected or mycoplasma free cells, each group comprising 5 mice. Experiments were conducted according to the French veterinary guidelines and those formulated by the European Commission for experimental animal use (L358-86/609EEC) and were approved by Inserm (National Institute for health and medical research, France).

\section{Mass spectrometry protein identifications}

Immunoisolation of Co-029-containing complexes and In-gel Tryptic Digestion-For identification of Co029 -associated molecules, cells were lysed in situ $\left(150 \mathrm{~cm}^{2}\right.$ 
flasks) with 3 lysis buffer/flask containing $10 \mathrm{mM}$ Tris, pH 7.4, $150 \mathrm{mM} \mathrm{NaCl}, 0,02 \% \mathrm{NaN} 3,1 \%$ Brij97 in the presence of protease inhibitors. Insoluble material was removed by centrifugation at $12,000 \mathrm{~g}$ for $15 \mathrm{~min}$, and the lysates were precleared three times successively with NHS-activated Sepharose ${ }^{\mathrm{TM}}$ High Performance, GE Healthcare beads coupled to BSA and to goat serum (Sigma). Isolation of Co-029 or CD9 containing complexes was performed using beads coupled to mAb TS29.2 or Ts 9 respectively. The beads were washed five times with lysis buffer, and the proteins were eluted by boiling for $3 \mathrm{~min}$ in in Laemmli buffer containing 0.1\% SDS. Brij97 was replaced by $1 \%$ Triton X100 for crosslinked extracts. The proteins were separated by $5-15 \%$ SDS-polyacrylamide gel electrophoresis under non-reducing conditions. For mass spectrometry analysis, the gels were stained with colloidal Coomassie Blue (Bio- Rad). The proteins were excised and destained in $200 \mu \mathrm{l} 0,1 \mathrm{M} \mathrm{NH4HCO3/}$ acetonitrile $\mathrm{v} / \mathrm{v}$ for $20 \mathrm{~min}$, centrifuged and swollen in $\mathrm{H} 2 \mathrm{O}$ repeatedly until complete destaining. Gel pieces were then incubated in $150 \mu 100 \%$ acetonitrile for 10 min and dried. This was followed by rehydratation in 100 $\mathrm{mM}$ ammonium bicarbonate containing $10 \mathrm{mM}$ DTT for $45 \mathrm{~min}$ at $56{ }^{\circ} \mathrm{C}$. After cooling to room temperature, the DTT solution was replaced with $55 \mathrm{mM}$ iodoacetamide in $100 \mathrm{mM}$ ammonium bicarbonate for $30 \mathrm{~min}$ at room temperature in the dark.

The gel pieces were washed in $300 \mu \mathrm{l} 0,1 \mathrm{M}$ $\mathrm{NH} 4 \mathrm{HCO} 3 /$ acetonitrile $\mathrm{v} / \mathrm{v}$ for $15 \mathrm{~min}$, dehydrated in $100 \%$ acetonitrile, and dried. For trypsin digestion, the Trypsin Profile IGD Kit-PP0100 (Sigma) for in gel digest was used according to manufacturer's instructions. Following enzymatic digestion overnight at $37^{\circ} \mathrm{C}$, and supernatant retrieval, the gels fragments were extracted twice by addition of $20 \mu \mathrm{l}$ of an Acetonitrile $/ 5 \%$ formic acid $70 / 30 \mathrm{v} / \mathrm{v}$ and incubation for $20 \mathrm{mn}$ at $37^{\circ} \mathrm{C}$ and supernatants were pooled, dried and rehydrated in Acetonitrile/formic acid/H2O 3/0.5/96 v/v.

LC-MS/MS analyses were performed using an ESI linear ion trap-Orbitrap hybrid mass spectrometer (LTQ-Orbitrap Velos, Thermo Fisher Scientific, Bremen, Germany) coupled on line with a nano-HPLC system (Ultimate 3000; Dionex) for liquid chromatography. $5 \mu \mathrm{l}$ digested protein were Injected in the system by using a pre-concentration column (C18 trap column - PepMap $\mathrm{C} 18,300 \mu \mathrm{mID} \times 5 \mathrm{~mm}, 5 \mu \mathrm{m}$ particle size and $100 \AA$ pore size; Dionex). The nano-column used in this study was a PepMap C18 reverse phase (Acclaim pepmap RSLC $75 \mu \mathrm{m}$ x $15 \mathrm{~cm}$, nanoViper C18, $2 \mu \mathrm{m}, 100 \AA)$. A linear $45 \mathrm{~min}$ gradient (flow rate, $300 \mathrm{nl} / \mathrm{min}$ ) from 4 to $55 \%$ acetonitrile in $0.1 \%(\mathrm{v} / \mathrm{v})$ was applied. After the acquisition of a full MS scan by the Orbitrap at high resolution (30000 resolution, $m / z$ range were 380-1700 $\mathrm{Da})$ in the first scan event, the five most intense ions present were subsequently isolated for fragmentation
(MS/MS scan). The collision energy for the MS/MS scan events was pre-set at a value of $35 \%$, isolation window was set at $3 \mathrm{Da}$, Dynamic exclusion option was enabled. The capillary voltage was set at $1.6 \mathrm{kV}$ and the temperature was $275^{\circ} \mathrm{C}$.

The data were analyzed by the Proteome Discoverer 1.4 software. The database is human (Swiss-Prot), the mass error for the precursor ions (full MS) is less than 10 ppm (error ${ }_{\text {ppm }}=\left(\mathrm{m} / \mathrm{z}_{\text {experimental }}-\mathrm{m} / \mathrm{z}_{\text {exact }}\right) \times 10^{6} / \mathrm{m} / \mathrm{z}_{\text {exact }}$. Mass error for ions from the MS/MS spectra is reported less than 0.6 Da. Peptides mass is searched between $350 \mathrm{Da}$ and $5000 \mathrm{Da}$ with time retention from $10 \mathrm{~min}$ to $50 \mathrm{~min}$. A miss cleavage site is tolerated. Dynamic modification was enabling for $\mathrm{N}_{\text {ter }}$ acetylation, oxidation of methionine and histidine, carbamidomethylation for amino acids, aspartic acid and glutamic acid. Dynamic modification $\mathrm{BS}^{3}$ was added for lysine in covalent bond experiments. Static carbamidomethyl modification of cysteine was enabled. Peptide identifications were validated by determination of false positives by Target decoy PSM validator. It is high if the false positive rate (FDR or false Discovery rate) is less than $1 \%$, low if the FDR is greater than 5\% and average (medium between 1 and $5 \%$ ). Peptide identification Xcorr were calculated by the correlation of MS/MS experimental spectrum compared with the theoretical MS/MS spectrum generated by the Proteome Discoverer 1.4 software. For analysis of mycoplasma proteins, a compilation of 91 Uniprot databases was used.

A relative quantitation was performed with the Proteome Discoverer integrated label free method which consists in comparing the mean peaks area of the three best peptides to a given protein from one sample to another. The method of calculation is three dimensional relying on retention time, ion intensity and $\mathrm{m} / \mathrm{z}$ ratio of the peptide, with a mass error lower than $2 \mathrm{ppm}$.

\section{Abbreviations}

ERM: Ezrin-Radixin-Moesin, RNAi: RNA interference, RTK: Receptor Tyrosine Kinase, siRNA: small interfering RNA, TLR: Toll Like Receptor.

\section{Author contributions}

YZ and NA performed the research, analyzed the data and wrote the manuscript; MSV, MB, FH, VN and RS performed selective experiments; AL and ER provided intellectual input by discussing the data and corrected the manuscript; $\mathrm{CB}$ and $\mathrm{CG}$ designed and performed the research, analyzed the data and wrote the manuscript.

\section{ACKNOWLEDGMENTS}

We thank Paule Opolon and Olivia Bawa for pathological studies. 


\section{CONFLICTS OF INTEREST}

No potential conflicts of interest were disclosed.

\section{FUNDING}

This work was supported by grants from the Agence Nationale de Recherche, the Association de Recherche contre le Cancer, the Association Nouvelles Recherches Biomédicales and the Association Institut du Cancer et d'Immunogénétique.

\section{REFERENCES}

1. Friedl $\mathrm{P}$, Wolf $\mathrm{K}$. Tumour-cell invasion and migration: diversity and escape mechanisms. Nat Rev Cancer. 2003; 3: 362-374.

2. Christofori G. New signals from the invasive front. Nature. 2006; 441: 444-450.

3. Trusolino L, Bertotti A, Comoglio PM. MET signalling: principles and functions in development, organ regeneration and cancer. Nat Rev Mol Cell Biol. 2010; 11: 834-848.

4. Greco C, Bralet MP, Ailane N, Dubart-Kupperschmitt A, Rubinstein E, Le Naour F, Boucheix C. E-cadherin/p120catenin and tetraspanin Co-029 cooperate for cell motility control in human colon carcinoma. Cancer Res. 2010; 70: 7674-7683.

5. Zoller M. Tetraspanins: push and pull in suppressing and promoting metastasis. Nat Rev Cancer. 2009; 9: 40-55.

6. Boucheix C, Rubinstein E. Tetraspanins. Cell Mol Life Sci. 2001; 58: 1189-1205.

7. Berditchevski F. Complexes of tetraspanins with integrins: more than meets the eye. J Cell Sci. 2001; 114: 4143-4151.

8. Hemler ME. Tetraspanin functions and associated microdomains. Nat Rev Mol Cell Biol. 2005; 6: 801-811.

9. Levy S, Shoham T. The tetraspanin web modulates immunesignalling complexes. Nat Rev Immunol. 2005; 5: 136-148.

10. Le Naour F, Andre M, Greco C, Billard M, Sordat B, Emile JF, Lanza F, Boucheix C, Rubinstein E. Profiling of the tetraspanin web of human colon cancer cells. Mol Cell Proteomics. 2006; 5: 845-857.

11. Charrin S, Le Naour F, Silvie O, Milhiet PE, Boucheix C, Rubinstein E. Lateral organization of membrane proteins: tetraspanins spin their web. Biochem J. 2009; 420: 133-154.

12. Charrin S, Jouannet S, Boucheix C, Rubinstein E. Tetraspanins at a glance. J Cell Sci. 2014; 127: 3641-3648.

13. Kawai T, Akira S. TLR signaling. Semin Immunol. 2007; 19: $24-32$

14. Miletic AV, Graham DB, Montgrain V, Fujikawa K, Kloeppel T, Brim K, Weaver B, Schreiber R, Xavier R, Swat W. Vav proteins control MyD88-dependent oxidative burst. Blood. 2007; 109: 3360-3368.

15. Schmidhauser C, Dudler R, Schmidt T, Parish RW. A mycoplasmal protein influences tumour cell invasiveness and contact inhibition in vitro. J Cell Sci. 1990; 95: 499-506.

16. Huang S, Li JY, Wu J, Meng L, Shou CC. Mycoplasma infections and different human carcinomas. World J Gastroenterol. 2001; 7: 266-269.

17. Ketcham CM, Anai S, Reutzel R, Sheng S, Schuster SM, Brenes RB, Agbandje-McKenna M, McKenna R, Rosser CJ, Boehlein SK. p37 Induces tumor invasiveness. Mol Cancer Ther. 2005; 4: 1031-1038.

18. Namiki K, Goodison S, Porvasnik S, Allan RW, Iczkowski KA, Urbanek C, Reyes L, Sakamoto N, Rosser CJ. Persistent exposure to Mycoplasma induces malignant transformation of human prostate cells. PLoS One. 2009; 4: e6872.

19. Barykova YA, Logunov DY, Shmarov MM, Vinarov AZ, Fiev DN, Vinarova NA, Rakovskaya IV, Baker PS, Shyshynova I, Stephenson AJ, Klein EA, Naroditsky BS, Gintsburg AL, et al. Association of Mycoplasma hominis infection with prostate cancer. Oncotarget. 2011; 2: 289-297. doi: 10.18632/oncotarget.256.

20. Rogers MB. Mycoplasma and cancer: in search of the link. Oncotarget. 2011; 2: 271-273. doi: 10.18632/ oncotarget.264.

21. Lo SC, Tsai S. Mycoplasmas and human prostate cancer: an exciting but cautionary note. Oncotarget. 2011; 2: 352-355. doi: 10.18632/oncotarget.282.

22. Elkind E, Rechnitzer H, Vaisid T, Kornspan JD, Barnoy S, Rottem S, Kosower NS. Mycoplasma hyorhinis upregulates calpastatin and inhibits calpain-dependent proteolysis in SH-SY5Y neuroblastoma cells. FEMS Microbiol Lett. 2010; 304: 62-68.

23. Akira S, Uematsu S, Takeuchi O. Pathogen recognition and innate immunity. Cell. 2006; 124: 783-801.

24. Shaykhiev R, Behr J, Bals R. Microbial patterns signaling via Toll-like receptors 2 and 5 contribute to epithelial repair, growth and survival. PLoS One. 2008; 3: e1393.

25. Rakoff-Nahoum S, Medzhitov R. Toll-like receptors and cancer. Nat Rev Cancer. 2009; 9: 57-63.

26. Kim S, Takahashi H, Lin WW, Descargues P, Grivennikov S, Kim Y, Luo JL, Karin M. Carcinoma-produced factors activate myeloid cells through TLR2 to stimulate metastasis. Nature. 2009; 457: 102-106.

27. Zoller M. CD44: can a cancer-initiating cell profit from an abundantly expressed molecule? Nat Rev Cancer. 2011; 11: 254-267.

28. Odintsova E, Sugiura T, Berditchevski F. Attenuation of EGF receptor signaling by a metastasis suppressor, the tetraspanin CD82/KAI-1. Curr Biol. 2000; 10: 1009-1012.

29. Murayama Y, Shinomura Y, Oritani K, Miyagawa J, Yoshida H, Nishida M, Katsube F, Shiraga M, Miyazaki T, Nakamoto T, Tsutsui S, Tamura S, Higashiyama S, et al. The tetraspanin CD9 modulates epidermal growth factor receptor signaling in cancer cells. J Cell Physiol. 2008; 216: 135-143. 
30. Park SY, Yoon SJ, Freire-de-Lima L, Kim JH, Hakomori SI. Control of cell motility by interaction of gangliosides, tetraspanins, and epidermal growth factor receptor in A431 versus KB epidermoid tumor cells. Carbohydr Res. 2009; 344: 1479-1486.

31. Lake D, Corrêa SA, Müller J. Negative feedback regulation of the ERK1/2 MAPK pathway. Cell Mol Life Sci. 2016; 73: 4397-4413.

32. Delos Santos RC, Garay C, Antonescu CN. Charming neighborhoods on the cell surface: Plasma membrane microdomains regulate receptor tyrosine kinase signaling. Cell Signal. 2015; 27: 1963-1976.

33. Berditchevski F, Odintsova E. ErbB receptors and tetraspanins: Casting the net wider. Int J Biochem Cell Biol. 2016; 77: 68-71.

34. Deng X, Li Q, Hoff J, Novak M, Yang H, Jin H, Erfani SF, Sharma C, Zhou P, Rabinovitz I, Sonnenberg A, Yi Y, Zhou P, et al. Integrin-associated CD151 drives ErbB2evoked mammary tumor onset and metastasis. Neoplasia. 2012; 14: 678-689.

35. Odintsova E, Voortman J, Gilbert E, Berditchevski F. Tetraspanin CD82 regulates compartmentalisation and ligand-induced dimerization of EGFR. J Cell Sci. 2003; 116: 4557-4566.

36. Alexi X, Berditchevski F, Odintsova E. The effect of cellECM adhesion on signalling via the ErbB family of growth factor receptors. Biochem Soc Trans. 2011; 39: 568-573.

37. Cailleteau L, Estrach S, Thyss R, Boyer L, Doye A, Domange B, Johnsson N, Rubinstein E, Boucheix C, Ebrahimian T, Silvestre JS, Lemichez E, Meneguzzi G, et al. alpha2beta1 integrin controls association of Rac with the membrane and triggers quiescence of endothelial cells. J Cell Sci. 2010; 123: 2491-2501.

38. Schwartz MA, Ginsberg MH. Networks and crosstalk: integrin signalling spreads. Nat Cell Biol. 2002; 4: 65-68.

39. Streuli CH, Akhtar N. Signal co-operation between integrins and other receptor systems. Biochem J. 2009; 418: 491-506.

40. Zuidscherwoude M, Gottfert F, Dunlock VM, Figdor CG, van den Bogaart G, van Spriel AB. The tetraspanin web revisited by super-resolution microscopy. Sci Rep. 2015; 5: 12201.

41. Ailane N, Greco C, Zhu Y, Sala-Valdes M, Billard M, Casal I, Bawa O, Opolon P, Rubinstein E, Boucheix C. Effect of an anti-human Co-029/tspan 8 mouse monoclonal antibody on tumor growth in a nude mouse model. Front Physiol. 2014; $5: 364$.

42. Park CS, Kim TK, Kim HG, Kim YJ, Jeoung MH, Lee WR, Go NK, Heo K, Lee S. Therapeutic targeting of tetraspanin8 in epithelial ovarian cancer invasion and metastasis. Oncogene. 2016; 35: 4540-4548.

43. Cajot JF, Sordat I, Silvestre T, Sordat B. Differential display cloning identifies motility-related protein (MRP1/CD9) as highly expressed in primary compared to metastatic human colon carcinoma cells. Cancer Res. 1997; 57: 2593-2597.

44. Bartolome RA, Molina-Ortiz I, Samaniego R, SanchezMateos P, Bustelo XR, Teixido J. Activation of Vav/ Rho GTPase signaling by CXCL12 controls membranetype matrix metalloproteinase-dependent melanoma cell invasion. Cancer Res. 2006; 66: 248-258.

45. Kissner TL, Moisan L, Mann E, Alam S, Ruthel G, Ulrich RG, Rebek M, Rebek J Jr., Saikh KU. A small molecule that mimics the BB-loop in the Toll interleukin-1 (IL1) receptor domain of MyD88 attenuates staphylococcal enterotoxin B-induced pro-inflammatory cytokine production and toxicity in mice. J Biol Chem. 2011; 286: 31385-31396.

46. Zahlten J, Steinicke R, Opitz B, Eitel J, N'Guessan PD, Vinzing M, Witzenrath M, Schmeck B, Hammerschmidt S, Suttorp N, Hippenstiel S. TLR2- and nucleotide-binding oligomerization domain 2-dependent Kruppel-like factor 2 expression downregulates NF-kappa B-related gene expression. J Immunol. 2010; 185: 597-604.

47. Pongcharoen P, Jinawath A, Tohtong R. Silencing of CD44 by siRNA suppressed invasion, migration and adhesion to matrix, but not secretion of MMPs, of cholangiocarcinoma cells. Clin Exp Metastasis. 2011; 28: 827-839.

48. Katome T, Obata T, Matsushima R, Masuyama N, Cantley LC, Gotoh Y, Kishi K, Shiota H, Ebina Y. Use of RNA interference-mediated gene silencing and adenoviral overexpression to elucidate the roles of AKT/protein kinase $\mathrm{B}$ isoforms in insulin actions. J Biol Chem. 2003; 278: 28312-28323.

49. Ji S, Shin JE, Kim YS, Oh JE, Min BM, Choi Y. Toll-like receptor 2 and NALP2 mediate induction of human betadefensins by fusobacterium nucleatum in gingival epithelial cells. Infect Immun. 2009; 77: 1044-1052.

50. Rasband WS. ImageJ, U. S. National Institutes of Health, Bethesda, Maryland, USA. http://rsb.info.nih.gov/ij/. 2007. 